PONTIFÍCIA UNIVERSIDADE CATÓLICA DO RIO DE JANEIRO

\title{
Mapeamento de Processos e Fluxogramas em Projetos de Grandes Eventos Aplicação Prática na área de Serviços do Evento dos Jogos Olímpicos do Rio de Janeiro 2016
}

Thyr Araguez Rodrigues

Trabalho de Conclusão de Curso

Centro de CIÊnCIAS SOCIAIS - CCS

DEPARTAMENTO DE AdMINISTRAÇÃO

Graduação em Administração de Empresas 
Thyr Araguez Rodrigues

Mapeamento de Processos e Fluxogramas em Projetos de

Grandes Eventos

Aplicação Prática na área de Serviços do Evento dos Jogos Olímpicos Rio de

Janeiro 2016

Trabalho de Conclusão de Curso

Trabalho de Conclusão de Curso, apresentado ao programa de graduação em Administração da PUC-Rio como requisito parcial para a obtenção do titulo de graduação em Administração.

Orientador(a) : Marcos Lopez Rego

Rio de Janeiro, novembro de 2015 


\section{Agradecimentos}

Gostaria de agradecer aos meus pais, Francisco e Mady. Meu irmão, Thoran. Meus amigos, lago, Leandro, Felipe, Pablo. Minha namorada, Mariana. E, finalmente, meu orientador, Marcos Lopes Rego, por confiarem na minha capacidade sempre, mesmo quando as circunstâncias que cercavam esse trabalho eram complicadas. 


\section{Resumo}

Rodrigues, Thyr. Mapeamento de Processos e Fluxogramas em Projetos de Grandes Eventos: Aplicação Prática na Área de Serviços do Evento dos Jogos Olímpicos do Rio de Janeiro 2016. Rio de Janeiro, 2015. 37 p. Trabalho de Conclusão de Curso - Departamento de Administração. Pontifícia Universidade Católica do Rio de Janeiro.

O objetivo desse estudo é, através de pesquisa descritiva participante, avaliar a impressão dos colaboradores do Comitê Organizador Rio 2016 sobre o impacto do uso do mapeamento de processos e de fluxogramas em projetos de grandes eventos. Mais especificamente no que tange a qualidade no desempenho de atividades voltadas para os espectadores dos Jogos Olímpicos do Rio de Janeiro 2016. De acordo com os colaboradores contemplados na pesquisa, o mapeamento dos processos operacionais da área de Serviços do Evento do Comitê Organizador Rio 2016 e os desenhos de seus fluxogramas são úteis como como fonte de conhecimento durante o projeto do evento e como fonte de consulta ao longo do evento em si.

Gerenciamento de Processos; Fluxogramas; Megaprojetos; Jogos Olímpicos; Serviços do Evento.

\section{Abstract}

Rodrigues, Thyr. Mapeamento de Processos e Fluxogramas em Projetos de Grandes Eventos: Aplicação Prática na Área de Serviços do Evento dos Jogos Olímpicos do Rio de Janeiro 2016. Rio de Janeiro, 2015. 37 p. Trabalho de Conclusão de Curso - Departamento de Administração. Pontifícia Universidade Católica do Rio de Janeiro.

The purpose of this study is to evaluate the opinion of Rio 2016 Olympics Local Organizing Committee employees on the impact of process mapping and management and use of flowcharts on mega events projects through the application of a descriptive research method. More specifically regarding the quality of spectator related activities for the Rio de Janeiro 2016 Olympic Games. According to the survey's participants the mapping of the operational processes of the Local Organizing Committee's Event Services functional area and the drawing of their flowcharts are useful as a knowledge source during the event planning phase and as consultation tool during Games time. 
Process Management; Flowcharts; Megaprojects; Olympic Games; Event Services. 


\section{Sumário}

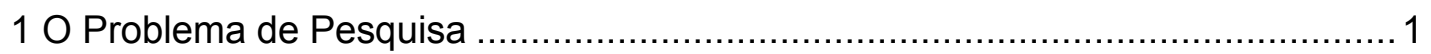

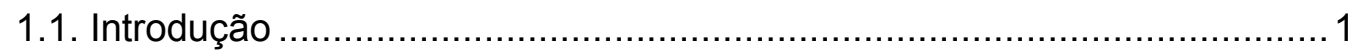

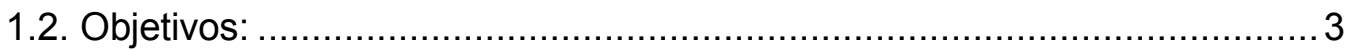

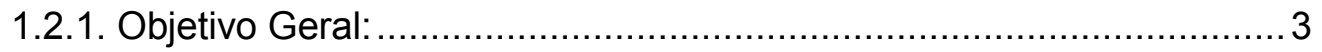

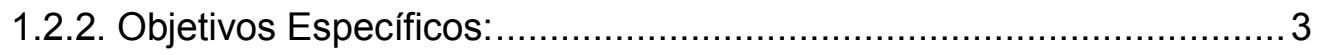

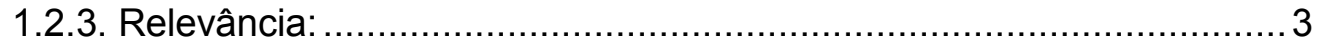

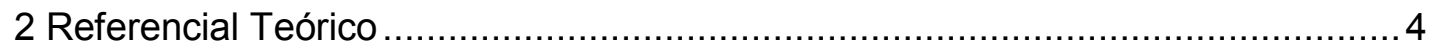

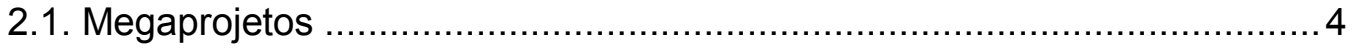

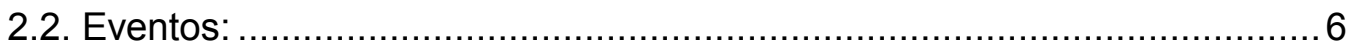

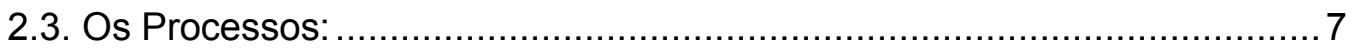

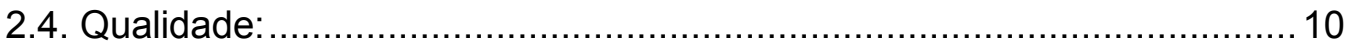

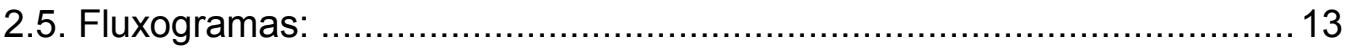

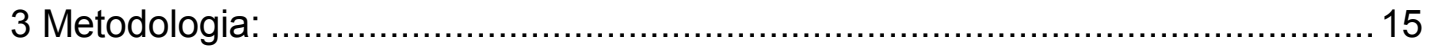

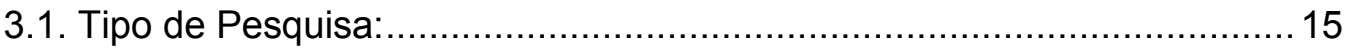

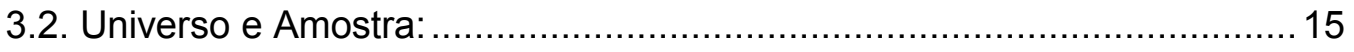

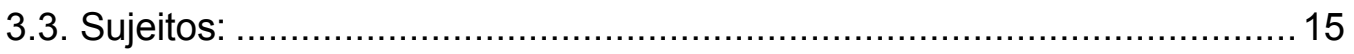

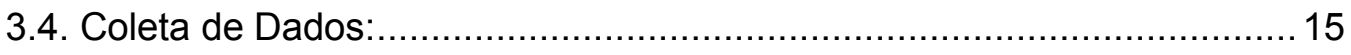

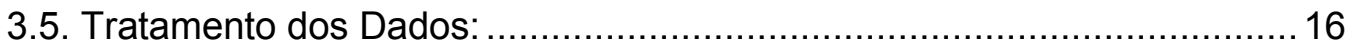

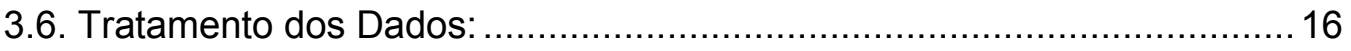

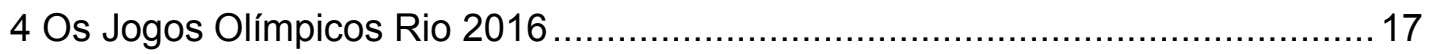

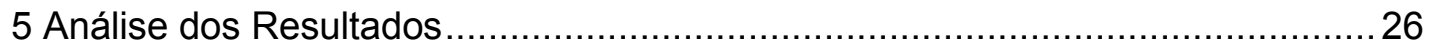

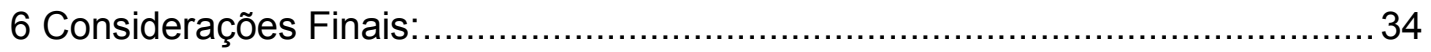

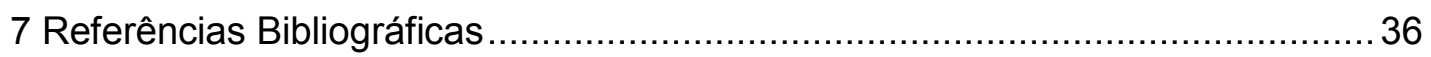




\section{Problema de Pesquisa}

\subsection{Introdução}

Com orçamento estipulado em torno de trinta e seis bilhões de reais (Rebello, 2014), os Jogos Olímpicos do Rio de Janeiro 2016 mostram todo seu peso em números e dados muito além dos financeiros. Uma das maiores audiências globais de televisão, as expectativas de pessoas assistindo ao evento simultaneamente chegam à cinco bilhões de pessoas (Vilf, 2015).

Cifras tão altas unidas aos olhares atentos de grande parte do planeta geram resultados distintos. O Brasil passou a ocupar durante os meses que precederam o evento e os da sua realização as atenções da mídia global, tendo seus aspectos culturais, políticos e econômicos observados e analisados. As atenções dos outros países não estão voltadas somente para os estádios mas para a sociedade brasileira.

Em alguns meses a expectativa e a cobrança não era só da população nacional mas também de todos os trezentos e oitenta mil turistas que, segundo a Embratur (Portal Terra, 2015) visitarão o país devido ao evento. Se alia a isso as determinações e exigências do COI para que os donos do seu produto, as seleções e seus jogadores, não fossem importunados no meio da teia operacional que é sediar um evento como esse.

Pensando justamente na qualidade do que vendem, COI e país-sede uniram-se na criação e operação do Comitê Organizador Rio 2016. Criado em 2008, dando sequência ao trabalho de candidatura do Brasil a sediar Os Jogos Olímpicos Rio 2016, o Comitê Rio 2016 dispôs de sete bilhões de reais (Comitê Organizador, 2015) para realizar essa entrega.

Todo esse valor foi destrinchado e diluído em mais de 100 instalações de competição com atuação direta de colaboradores em Aeroportos Internacionais e Domésticos, hotéis oficiais da competição, centros de treinamento das seleções, centros de distribuição de ingressos e estádios. No auge do evento toda a operação contará com mais de 138 mil integrantes da força de trabalho, dentre os quais mais de 20.000 voluntários.

O Comitê Rio 2016 é uma estrutura organizacional matricial coordenada a partir de seu Escritório Central no Rio de Janeiro. Dele surgem as premissas conceituais a partir das quais todo o planejamento operacional é desenhado. Em cima desse planejamento as atividades de cada Área Funcional são replicadas nas instalações.

Todas as atividades de suporte da entrega principal, as inúmeras competições esportivas, também são coordenadas a partir do Escritório Central e reproduzidas em menor escala nos locais de prova. Por exemplo: o recebimento, armazenamento e distribuição de materiais logísticos do evento é concentrado no Escritório Central. A partir disso cada instalação recebe, armazena e distribui os equipamentos relativos à competição que acontecerá ali. 
Para que os oito milhões de espectadores tenham o nível de serviço determinado pelo COI para os clientes é necessária a formação de uma estrutura organizacional voltada exclusivamente para a entrega da competição. Ou seja, áreas funcionais e áreas de apoio atuando em conjunto em prol do mesmo objetivo.

Departamentalizado e estruturado com metas claras e objetivos específicos o Comitê Rio 2016 e suas áreas funcionais adotam técnicas da administração nas gestões do planejamento e da operação do evento. Sob o ponto de vista dos negócios, o Comitê é um prestador de serviço contratado pelo COI para entregar produtos aos clientes desse último: espectadores, atletas, patrocinadores, membros da imprensa.

Estratégias de marketing, serviços e atendimento, mapeamento de processos, gestão da qualidade e desenho de fluxogramas foram iniciativas da área de Serviços de Evento para a estruturação de suas entregas. Cabe à área, de acordo com o descritivo de suas atividades, atender, orientar e auxiliar os clientes dos Jogos quando os mesmos se encontram dentro das instalações esportivas nos horários de competição.

Em cima desses conceitos da administração Serviços de Evento entende que a qualidade das suas atividades está na consistência: no Parque Olímpico de Deodoro e na Lagoa Rodrigo de Freitas as informações transmitidas e os serviços prestados devem ser iguais.

Todo o capital dispendido, planejamento realizado e trabalho executado estão sendo necessários para que os Jogos Olímpicos do Rio de Janeiro 2016 tenham aceitação popular local, melhorem a percepção dos estrangeiros sobre o Brasil e consagrem a sua organização como bem-sucedida.

Como objetivos complementares estão geração e gestão de conhecimento relativo a realização de grandes eventos no Brasil. Entregas da área de Serviços de Evento como locomoção de clientes em cadeiras de rodas, achados e perdidos de objetos e pessoas e identificação infantil poderão ser disponibilizadas em qualquer tipo de evento, especialmente os de maior porte.

A documentação de políticas e procedimentos operacionais de todas as Áreas Funcionais e de Apoio do Comitê Rio 2016 servem, por exemplo, como padrão e parâmetro para a realização das mesmas atividades, ou outras conceitualmente similares, em oportunidades futuras.

Qual é, portanto, na visão dos organizadores de eventos, o impacto da utilização do mapeamento de processos das atividades desempenhadas pelas áreas operacionais na realização de projetos de eventos? 


\subsection{Objetivos:}

\subsubsection{Objetivo Geral:}

Avaliar a influência do mapeamento de processos e fluxograma de processos no treinamento e na execução das tarefas operacionais em grandes eventos. Contribuir para a estruturação de projetos de grandes eventos.

\subsubsection{Objetivos Específicos:}

- Avaliar a influência do mapeamento de processos em projetos de megaeventos;

- Observar a impressão de profissionais com experiência em eventos, que trabalham no Comitê Rio 2016, sobre a utilização de desenhos de fluxogramas de processos das atividades que serão desempenhadas nos Jogos Olímpicos Rio 2016 no planejamento dos mesmos.

\subsubsection{Relevância:}

114 instalações, dez mil atletas, 143 mil pessoas atuando como força de trabalho, quarenta e uma modalidades olímpicas ao longo de dezessete dias de evento. Esses são os Jogos Olímpicos e Paralímpicos Rio 2016.

Tamanha densidade populacional e, consequentemente, estrutura urbana da cidade-sede exigem muito planejamento e estruturação por parte de quem está responsável pela execução do projeto. Esse trabalho, portanto, visa analisar a influência da utilização de processos e fluxogramas na organização e treinamento dos colaboradores participantes dos Jogos Olímpicos Rio 2016 e outros eventos de grande porte.

O Brasil vem de uma evolução recente na realização de grandes eventos esportivos: em 2007 foram os Jogos Pan Americanos, 2011 os Jogos Mundiais Militares, 2014 a Copa do Mundo da FIFA e em 2016 serão as Olimpíadas. Com os olhares esportivos virados para o país outros tipos de atenção também surgem e atraem outros mega-eventos ao demonstrar seu potencial de consumo para os mesmos e a capacidade estrutural de sediá-los.

Nesse meio tempo o Rio de Janeiro, mais especificamente, tornou-se palco de mais duas edições do Rock in Rio e dos NBA Global Games, as partidas internacionais da maior liga de basquete do mundo. Na história apenas a Espanha teve o privilégio de mesclar o ciclo de uma Copa do Mundo com o ciclo olímpico e, no seu caso, o intervalo entre os mesmos foi maior do que o brasileiro.

Percebe-se então a relevância dessa oportunidade única oferecida ao Brasil e o impacto do legado que pode ser deixado. Investimentos econômicos feitos pelo próprio governo e a injeção de capital por partes estrangeiras tem a capacidade de causar impactos duradouros na infraestrutura do país. A gestão do conhecimento produzido e adquirido durante o planejamento e a realização desses eventos gerará conteúdo acadêmico para a aplicação do mapeamento de processos e fluxogramas em grandes eventos e causará impactos na capacidade e atratividade do país para sediar novos megaprojetos. 


\section{Referencial Teórico}

\subsection{Megaprojetos}

De acordo com Flyvbjerg (2014) megaprojetos tem as seguintes características: são empreitadas complexas e com grande escala; custam a partir de um bilhão de dólares; levam anos para serem desenvolvidos e construidos; envolvem stakeholders públicos e privados; promovem transformações aonde estão inseridos e impactam milhões de pessoas. Ao mesmo tempo, eles são desenvolvidos com a ambição de alterar, mesmo que temporariamente, a estrutura da sociedade na qual se encontram. Contrastam, portanto, com projetos de menor porte que acabam por ter que se adaptar ao cotidiano do local onde serão realizados.

Gerenciar o crescimento da escala dos megaprojetos é uma questão constante atualmente, já que eles estão crescendo em tamanho e também em quantidade. Em 2013 o McKinsey Global Institute estimou que os gastos globais em infraestrutura (um das principais formas na qual os megaprojetos são realizados) serão três trilhões de dólares por ano entre 2013 e 2030 , o equivalente a quatro porcento do produto interno bruto do período.

Ainda de acordo com esse estudo, se levado em consideração os âmbitos nos quais os megaprojetos são um modelo comum de entrega (óleo e gás, mineração, aeroespacial, defesa de fronteiras, cadeias de fornecimento e megaeventos) a estimativa conservadora para o mercado global de megaprojetos é entre seis e nove trilhões de dólares por ano, ou em torno de oito porcento do produto interno bruto global.

Tantos recursos em tantos megaprojetos fazem com que seu gerenciamento esteja em seu momento de maior importância. De acordo com Flyvbjerg (2014) os benefícios de realização e entrega dos projetos corretos, da maneira correta, só são superados pelo desperdício de realizar os projetos errados ou de maneira errada. Nesse sentido, o conhecimento sobre a estrutura de megaprojetos atualmente é relevante como meio de informar os meios político, profissional e público sobre essa área que envolve cifras, públicas e/ou privadas, tão grandes.

O interesse por essa informação é grande, principalmente por parte dos políticos que ganharão visibilidade ao se envolverem, já que megaprojetos concentram as atenções dos públicos que os cercam, dão uma imagem de pró-atividade para quem os promove e são ímãs de mídia. A monumentalidade única e importância histórica dos megaprojetos gera o tipo de exposição pública que faz com que os governantes busquem se associar eles.

Para os políticos, o investimento em megaprojetos é interessante porque, se realizados corretamente, eles podem: criar e sustentar empregos, beneficiar os 
consumidores através de serviços de maior qualidade e causar impactos positivos de sustentabilidade. No entanto, como estabeleceu Flyvbjerg (2006), eles possuem riscos inerentes ao seu longo horizonte de planejamento e suas interfaces de relacionamento complexas.

No entanto, segundo (Flyvbjerg, 2006) não raro os megaprojetos são gerenciados por colaboradores sem tanta experiência no assunto e que acabam sendo substituídos ao longo do ciclo do projeto e enfraquecendo a liderança do mesmo como um todo. Essa liderança e relacionamento são muito relevantes, pois, de acordo com Aaltonen \& Kujala, (2010) o planejamento, tomada e gerenciamento de decisões em megaprojetos são processos que envolvem diversos agentes, públicos e privados, com interesses conflitantes.

Evidências estatísticas demonstram que a complexidade e imprevisibilidade das atividades que compõem os projetos tendem a ser ignoradas nas etapas de planejamento, tornando as contingências de tempo e orçamento inadequadas. Consequentemente informações erradas sobre custos, cronogramas, benefícios e riscos são consideradas comuns ao longo dos períodos de desenvolvimento e tomada de decisões dos megaprojetos. Isso resulta em: orçamentos extrapolados, atrasos e perda de benefícios. Tudo isso tira o crédito da viabilidade do projeto durante sua implementação, entrega e operação.

Frequentemente há um compromisso exagerado com conceitos específicos do projeto apresentados em etapas iniciais e se deixa de lado análises de alternativas. Isso leva ao comprometimento em escala nas etapas finais dos megaprojetos, que acabam por "falhar aos poucos" como definiram Cantarelli, Flyvbjerg, \& Rothengatter, (2010); Ross \& Staw, (1993); Drummond (1998). Design de projeto e iniciativas tecnológicas não costumam ser padronizadas, levando à características únicas do projeto e dificultando a transmissão de conhecimento.

Conforme estabeleceu Taleb (2010) a entrega dos megaprojetos é uma atividade de alto risco com grande exposição aos chamados "cisnes negros", ou seja, eventos extremos com grandes consequências negativas. A tendência é que seus gestores ignorem esse risco e tratem os projetos como uma série de atividades determinísticas.

Um megaprojeto pode, portanto, ser um fracasso financeiro, mas um sucesso nos outros âmbitos que abrange. A ideia chave é que para manter os custos baixos as fases de implementação do projeto e seus atrasos devem ser curtos. No entanto, isso não deve ser visto como um motivo para acelerar a etapa de tomada de decisões para que sua construção rapidamente se inicie. Pelo contrário: o planejamento inicial de um megaprojeto deve ser extenso antes de se decidir por aprova-lo ou rejeita-lo.

Até mesmo economias nacionais podem ser impactadas pela falha de um único megaprojeto. Na Grécia, por exemplo, um fator que contribuiu para o déficit público registrado em 2011 foi a realização dos Jogos Olímpicos de Atenas 2004, nos quais as dívidas que vieram com o estouro do orçamento do projeto foram tão significativas que afetaram a nota de crédito do país e enfraqueceram a economia do país poucos anos antes da crise financeira mundial de 2008. De maneira similar, a tragédia de Fukushima, no Japão, em 2011 prejudicou a economia japonesa como um todo. Cada vez mais percebe-se que bastam os efeitos negativos de um único megaprojeto para arrasar toda uma nação.

Em geral, um megaprojeto de sucesso implica que o mesmo é entregue no prazo, dentro do orçamento previsto e atinge os benefícios prometidos. Se, como as evidências demonstram, um em cada dez megaprojetos finaliza dentro do seu prazo, 
um em cada dez não estoura seu orçamento e um em cada dez apresenta os benefícios prometidos então um em cada mil megaprojetos pode ser considerado bem-sucedido. É a "Lei de Ferro dos Megaprojetos": acima do orçamento e atrasado, novamente.

Sendo assim mantem-se o "paradoxo dos megaprojetos" identificado por Flyyberg et al. (2003): De um lado o uso dos megaprojetos como meio de viabilizar a entrega de empreendimentos públicos e privados nunca esteve mais em voga do que agora, assim como o tamanho e frequência dos megaprojetos também está no auge. Do outro lado, o desempenho da gerência de megaprojetos está aquém das expectativas e não apresentou melhoras em termos de custo, prazo e benefícios nos últimos 70 anos dos quais se dispõem de dados comparativos.

Diferente das empresas, megaprojetos tem tempo de vida predeterminado. Portanto um dos objetivos fundamentais dos projetos, mega ou não, é adquirir e usufruir de seus recursos de maneira que eles se esgotem ao final do projeto. E a chave para levar um projeto "à falência" no momento certo é a percepção, por parte do gerente do projeto, que "falir" deve ser um processo controlado e bem planejado.

Nesse sentido, portanto, é importante que a missão do projeto se mantenha constante e em evidência ao longo da duração do mesmo. Por outro lado, os objetivos dos projetos podem ser enxergados como entregas de curto prazo que se adaptam às mudanças de condições dos projetos. É muito comum que as equipes do projeto foquem em metas e objetivos de curto prazo e esqueçam da sua missão, podendo gerar uma realização tardia de que essa missão é inalcançável.

\subsection{Eventos:}

Com data e local específicos, um evento é uma reunião de pessoas ou entidades que pode representar e comemorar acontecimentos comerciais, culturais e/ou esportivos. Como estabelece Zanela (2012, p.1), “Um evento geralmente provoca fortes emoções para os participantes, para os promotores e organizadores e, enfim, para todos que convivem com o turbilhão de atividades que compõem seu universo".

Dentre os eventos de maior destaque, os esportivos atualmente estão entre os que causam maior impacto no local que ocorrem devido ao seu potencial de consumo e consequente força econômica. Quando bem conduzidos por todos os seus organizadores durante suas etapas de planejamento, entrega e pós-avaliação os eventos "Colaboram para assegurar a estabilidade da atividade econômica(...)" (Zanela, 2012, p.3). Espanha e Grécia são exemplos disso.

Mas o objetivo principal da realização de grandes eventos, sejam eles esportivos ou não, não consiste em tornar os saldos dos Governos locais superavitários. Todo o trabalho, iniciativa, criatividade e competência dos que trabalham no evento são voltados para atender às expectativas dos seus participantes. Zanela (2012, p.1) definiu as expectativas desses envolvidos como: "[...] congraçamento e integração, gerando e consolidando vínculos e relações de caráter profissional e pessoal”.

O Comitê Olímpico Internacional, responsável pela coordenação mundial das atividades relacionadas aos esportes olímpicos, criou uma forma única de celebrar os esportes que ela regula: os Jogos Olímpicos. Essa festa do esporte tem tanto apelo de consumo e ganhou tanta importância ao longo das suas edições que se tornou um 
produto valioso e de grandes proporções, o qual o próprio COI não tem condições de "fabricar".

Tamanha mobilização popular em torno desses eventos exige profissionalização no seu planejamento e entrega, além de coordenação centralizada. Segundo Zanela (2012, p.30) "[...] a operacionalização de um evento abrange a integração das diversas atividades técnicas nas respectivas especializações através de uma unidade responsável [...]". Ou seja, reunião de todas as Áreas Funcionais sob uma única Gerência. o COI não possui tanto essas especializações quanto a capacidade de gerenciá-las justamente porque sua finalidade não é a realização de eventos.

Para receber com qualidade todas as mais de 200 delegações estrangeiras e, segundo a Embratur, mais de 400 mil turistas estrangeiros em uma única cidade com tamanha densidade populacional como o Rio de Janeiro foi preciso criar um Comitê Organizador formado por colaboradores exclusivamente dedicados. É responsabilidade do Comitê Rio 2016 planejar, organizar e entregar os Jogos Olímpicos do Rio de Janeiro 2016.

Como em qualquer outro evento de grande porte, os órgãos organizadores precisam garantir que os participantes tenham condições de chegar, ficar e sair do país e das instalações do evento com segurança, bem-estar e tranquilidade. Dentro desses três pontos está compreendido prover banheiros limpos, luz, água, internet, sistema de som, alimentos e bebidas, atendimento médico e tudo mais que possa ser preciso para atender às necessidades dos clientes.

\subsection{Os Processos:}

"']...]uma ordenação específica de atividades de trabalho no tempo e no espaço, portanto, devem ter começo, fim, insumos e resultados claramente identificados." (Araujo, 2007). Em outras palavras, processo significa sempre realizar as atividades da mesma maneira seguindo uma sequência previamente estabelecida.

Utilizar processos exige preparações relativas ao processo em si, quem o realiza e a quem ele é direcionado. Antes do registro e da avaliação conclusiva dos dados do processo como um todo, etapas mais trabalhosas, a compreensão das preocupações de todos os envolvidos e de todos os elementos que compõem os processos é essencial para a eficácia do mapeamento e desenvolvimento de um processo.

Os insumos ocupam a primeira posição entre esses elementos e podem ser definidos como todos os materiais que, direta e/ou indiretamente, estão envolvidos na produção dos bens e serviços. Madeira, água ou minério são exemplos de insumos para ambos, bens ou serviços já que os insumos não precisam, necessariamente, fazer parte do resultado final do processo.

Os segundos elementos que compõem os processos são os recursos e definemse como os meios através dos quais os insumos são transformados. Ao darem suporte à produção do bem ou serviço, são recursos como o capital disponível, a mão-de-obra, os equipamentos e as instalações que determinam a capacidade produtiva da empresa para seu produto final. 
Com a presença dos insumos e dos recursos, as atividades são os próximos elementos que compõem os processos. É através delas que os recursos utilizam os insumos para transformá-los no produto final desejado pela organização. Dentro de um processo as atividades são, portanto, a parte mais mecânica e objetiva: tarefas específicas com execução ordenada a fim de se atingir determinado resultado.

Mesmo sendo consideradas as menores partes dos processos (Cruz, 2007, P.108), as atividades são compostas por dois fatores diferentes: informações e procedimentos. É para determinar o que será realizado pela atividade, o porque de sua existência, a quem ela está subordinada e qual será seu produto resultante que as informações das atividades existem. É comum que o nome de determinado processo venha dessas informações como, por exemplo: contas a pagar, contas a receber, etc.

Por sua vez, os procedimentos são utilizados para determinar como a atividade será realizada, as ferramentas utilizadas para tanto e a forma como essas se aplicarão. Pelo fato de poderem envolver um componente humano, ou seja, uma pessoa realizando esses procedimentos, eles também apresentam uma subdivisão entre: formais e informais.

Os procedimentos formais são aqueles que, segundo Cruz $(2007$, p.108) "[...]até mesmo de forma oral, são transmitidos como os que devem ser executados na atividade. " Ou seja, eles possuem um certo caráter oficial.

Já os procedimentos informais são aqueles criados exclusivamente por um ocupante do cargo responsável pela atividade. Isso significa que não houve qualquer determinação prévia sobre aquele modo de realizar a atividade, foi com a experiência prática que o realizador da atividade percebeu aquela maneira de agir como sendo a ideal. "[...] São, também, estabelecidos pela prática que o ocupante adquire ao executar uma atividade e pelos anos de convivência com determinado equipamento." (Cruz, Tadeu. 2007, p.109).

Disponíveis insumos e recursos e definidas as atividades por meio de informações e procedimentos claros, formais e informais, o tempo é o próximo elemento que compõe os processos. Nesse caso ele assume dois papéis: determinar a ordem cronológica nas quais as etapas do processo ocorrem e a duração das mesmas.

Ordenar as etapas de um processo é necessário quando o mesmo tem longa duração ou envolve diversos estágios. O mapeamento, a definição e o respeito à sequência correta de tarefas que compõem um processo evita o retrabalho e a realização de atividades desnecessárias. Quando todos os envolvidos compreendem todas as etapas do processo e o porquê da ordem das mesmas há ganhos de eficiência na organização como um todo.

Em relação à duração das etapas, o tempo de determinado processo permite que se coloquem todas as etapas a serem realizadas dentro de uma perspectiva prática. Ou seja, faz com que seja possível avaliar se o processo como um todo, ou alguma etapa específica, é mais lento ou mais rápido do que o ideal para a empresa. Esse componente é muito importante para, por exemplo, processos relativos a produtos com prazo de entrega ou que utilizam insumos perecíveis.

Último elemento que compõe os processos, os objetivos se destrincham em dois componentes: metas e clientes, ambos diretamente relacionados. Balisando todos os outros elementos, metas são "Objetivos mensuráveis do processo. O que produzir, em quais quantidades, com qual qualidade e em quanto tempo." (Cruz. 2007, p.109) e devem ser estabelecidas por parte da empresa antes do início do processo. 
O mesmo vale para os clientes, que são o "Principal objetivo de qualquer processo. " (Cruz. 2007, p.109) e podem ser internos e externos. "Clientes internos são todos aquelesque desempenham atividades dentro da própria empresa. " (Cruz, 2007, p.109). Já os clientes externos "[...]são aqueles que vão comprar e receber os bens ou serviços produzidos pela empresa. " (Cruz. 2007, p.110).

No caso da Área Funcional de Serviços de Evento do Comitê Organizador dos Jogos Olímpicos Rio 2016, os clientes externos são os oito milhões de portadores de ingressos para as 43 competições olímpicas que serão disputadas. Os internos, por sua vez, são outras Áreas Funcionais do Comitê cujas atividades dependem das entregas de Serviços de Evento como, por exemplo: Credenciamento e Ticketing.

Identificar as expectativas daqueles que utilizarão o produto final do processo é útil para traçar as metas objetivas e também as subjetivas, como a qualidade esperada. Seja ele voltado para o cliente interno (da própria empresa) ou externo (consumidor final), para o produto atingir o que dele se espera são tomadas iniciativas concretas dentro das etapas que compõem os processos.

Por exemplo: um fabricante de móveis buscando atender clientes com renda per capita alta pode identificar que esses esperam encontrar requinte, durabilidade e sofisticação nos sofás e camas que adquirem. Com clareza sobre essa expectativa o fabricante pode estabelecer metas como a produção de móveis utilizando tecidos e madeiras melhores do que as atuais com uma montagem mais manual e artesanal. Ou seja, alterar os insumos e as atividades utilizadas no processo de produção de seus móveis para que, mesmo ao custo de um aumento na duração e no custo do processo, os clientes com maior poder aquisitivo enxerguem mais qualidade no produto final.

Independente de qual seja a expectativa do cliente externo ou interno ao qual o produto ou serviço é destinado, a importância dos processos está, portanto, na possibilidade de identificar todos os fatores envolvidos na produção para que a entrega final seja padronizada, sempre com a mesma qualidade esperada. 


\subsection{Qualidade:}

Segundo Araujo (2007, p.231) foram os norte-americanos, durante a Segunda Guerra Mundial, que deram os primeiros passos na direção do avanço da qualidade na fabricação. Sua motivação para tanto não era à toa. Padronização e eficácia da produção de materiais bélicos eram mais do que uma questão de qualidade, significavam sobrevivência nas indústrias e no campo de batalha. Armas tinham que disparar balas corretamente na hora do confronto e balas de canhão não poderiam explodir durante sua confecção. Nessa época surgiram os primeiros modelos norteamericanos de controle de qualidade através de métodos estatísticos, como o criado por Walter Andrew Shewart.

Com o final da Segunda Guerra foram os japoneses que a tomaram a frente e assumiram a liderança nesse conceito. Uma economia devastada pela derrota no campo de batalha e um país com poucos insumos naturais disponíveis para abastecer a produção implicavam que o Japão precisava ter indústrias eficientes. "[...]os japoneses[...] descobriram que as até então aceitáveis margens de erro podiam ser reduzidas a níveis extremamente baixos. " (Araujo, 2007, p.227).

Além disso, para sanar a dívida financeira acumulada com a Segunda Guerra não bastava vender somente para seu mercado interno, extremamente fragilizado no momento e também sendo "invadido" por produtos estrangeiros. Os japoneses também teriam que exportar seus bens e serviços. Era preciso que eles fossem competitivos interna e externamente. A estratégia japonesa se iniciou com a "importação" de especialistas em qualidade norte-americanos

W.E. Deming, Joseph M. Juran e o próprio Shewart foram contratados pelo governo nipônico para, em conjunto com a Union of Japanese Scientists and Engineers, promover uma revolução da qualidade no país. A base do método de qualidade desenvolvido foi além da eliminação de peças defeituosas nas esteiras das fábricas. Os japoneses queriam se antecipar aos problemas e evitar que os defeitos na produção ou prestação do serviço ocorressem.

Esse novo olhar sobre a fabricação permitiu ganhos em eficiência nessa etapa e produtos japoneses diferenciados em relação aos quais eles competiam: nos quesitos durabilidade, tamanho ou preço o que era produzido no Japão muitas vezes tinha mais qualidade do que o produto estrangeiro a um preço competitivo ou mais baixo.

Com mais produtos locais, e agora também produtos estrangeiros, ao alcance do consumidor, o conceito de qualidade extrapolou os limites da fábrica e passou a abranger também a percepção do cliente sobre o que ele estava consumindo. A preocupação agora também era atender às expectativas do potencial consumidor para que ele optasse por um produto frente a todos os outros que estavam disponíveis para a mesma "função".

Mais ainda, os japoneses adotaram a visão de Juran (1992) de que "[...] baixos níveis de qualidade constituem uma ameaça à sociedade, já que os produtos existem para gerar benefícios contínuos e adequados a seus consumidores, e não para ocasionar problemas, prejuízos ou mesmo dano em razão de defeitos. " (Araujo, 2007, p.229). 
Confirmava-se, portanto, a posição estabelecida por Luiz Cesar de Araujo (2007, p.229) de que existem dois escopos sob os quais a qualidade pode ser enxergada: "[...] a qualidade do ponto de vista de quem produz e a qualidade do ponto de vista de quem consome [...]". Apesar de o primeiro ser mais objetivo do que o segundo, ambos estão relacionados. Produtos e/ou serviços produzidos com garantia técnica de bom funcionamento tem maior possibilidade estarem adequados a ou superarem o que o cliente espera.

A introdução dessa nova variável na equação da qualidade e a observação das experiências Norte-americana e Japonesa demonstrou que o alcance da qualidade, para quem produz e para quem consome, dependia tanto de planejamento quanto de controle. Gerenciar a qualidade em ambos os lados foi um dos fatores motivadores para criação do Instituto e das normas ISO.

O objetivo da Instituição ISO era aproveitar as normas e orientações de produção já existentes nos países mais desenvolvidos da época para criar uma coordenação produtiva única. Com isso surgiria um padrão internacional que poderia ser aplicado e controlado em qualquer lugar.

A importância do estabelecimento de parâmetros internacionais de qualidade produtiva e do produto final era maior, principalmente, para os países industrialmente mais atrasados. A ISO servia como uma fonte de conhecimento tecnológico, de especificações do produto e do seu desempenho para aqueles que davam seus primeiros passos industriais. Com isso beneficiava também os consumidores ao aumentar a oferta de produtos com maior padrão de qualidade.

Para que os produtos alcançassem esses parâmetros claramente definidos e fossem escolhidos entre os outros disponíveis planejar para a qualidade ganhou importância. "A fórmula de sucesso para a qualidade definida por Juran (1992) confirma essa necessidade: "Estabelecer metas específicas a serem atingidas; Estabelecer planos que indiquem como atingir essas metas; Atribuir responsabilidades definidas para se obter os resultados e recompensar com base nos resultados alcançados. " (Araujo, 2007, p.230).

Todos esses pontos são mais facilmente atingidos através da utilização de ferramentas e técnicas como, por exemplo, o mapeamento de processos e seu desenho com fluxogramas. Já que é o conjunto de atividades específicas realizadas por determinadas pessoas que compõe os planos usados para o alcance das metas de qualidade definidas.

Ou seja, a definição prévia da realização correta de diversos processos por pessoas específicas de maneira ordenada leva à qualidade do resultado dos mesmos. A busca pela qualidade nas empresas ocorre quando "[...] todo esforço é documentado, de sorte que as pessoas da organizaçào possam visualizar onde, como, por que e quando suas atividades afetam a qualidade. " (Araujo, 2007, p.233).

Assim, ao traçarem a maneira correta de realizar as atividades que formam os processos antes que os mesmos se iniciem os fluxogramas contribuem diretamente para a qualidade do que é entregue ao consumidor final. Pois a soma de diversas atividades realizadas com qualidade resulta em um bom produto ou serviço.

Da mesma maneira que uma fábrica possui diversas etapas produtivas até que o produto final seja entregue, ou um prestador de serviço realiza diversas outras tarefas anteriores para fazer o que lhe foi pago, um evento também acontece devido à soma de inúmeras atividades. Sendo assim, há espaço para a aplicação de mapeamento de processos com fluxogramas em eventos. 
Como empresas, eventos também possuem diversas áreas operacionais que precisam estar integradas para a realização de seus processos, produtivos ou não. No entanto, por ser algo pontual e único, mesmo as atividades realizadas repetitivamente nos eventos tem "prazo de validade". Tanto sua fase de planejamento quanto seu período de realização são limitados, enquanto uma organização pode repetir seus processos administrativos-financeiros, por exemplo, pelo tempo que ela existir.

Como estabeleceu Araujo (2007, p.56 ), processos "Aplicam-se a qualquer coisa, desde fluxo de materiais até etapas de venda ou manutenção de produtos." mas a limitação do fator tempo faz com que não seja comum a adoção de fluxogramas de processos por parte dos organizadores de eventos. Durante os oito anos de existência do Comitê Organizador dos Jogos Olímpicos Rio 2016 poucos foram os processos mapeados e desenhados, mesmo com a alta complexidade das entregas necessárias.

No caso de uma partida de volêibol de quadrea masculino dos Jogos Olímpicos Rio 2016, por exemplo, o processo de chegada de uma equipe à Arena para sua partida envolve coordenação entre as Áreas Funcionais internas do Comitê e agentes externos: O setor de Transportes será responsável por enviar o ônibus da delegação e traçar a melhor rota até a arena; Segurança deverá solicitar e alinhar a escolta policial do percurso; A área de Competições Esportivas passará as orientações de horários do ônibus para a Seleção Nacional que irá jogar; Enquanto todas as equipes operacionais que atuam na arena devem deixar a mesma pronta para receber as Seleções, os espectadores e a própria partida.

Tal processo aumenta de complexidade devido a importância e proporção do evento. Porém esses aspectos também justificam a maior utilidade da aplicação de fluxogramas de processos. O mapeamento deles contribuirá para replicar tais atividades nas 43 competições das diferentes modalidades sem atrasos ou execução de tarefas desnecessárias. Ou seja, com qualidade para quem realiza a entrega e para o seu consumidor final.

Quanto mais pessoas envolvidas na realização das atividades que compõem um processo, maior a importância de que todos dominem as tarefas que vão realizar e compreendam seu espaço e relevância na produção da entrega. Contudo, isso não significa que o desenho de processos não seja aplicável em eventos menores, assim como em empresas com poucos colaboradores.

A definição do que deve ser feito, e da forma como deve ser feito, traz ganhos de eficiência até em processos com poucas atividades ou que sejam realizados por apenas uma pessoa. Ou seja, "[...] atribuir responsabilidades definidas para se obterem resultados [...]" (Araujo, 2007, p.230). Ainda, fluxogramas desenhados reduzem a chance de que a organização ou o evento dependam de um único colaborador para realizar sua entrega ao facilitarem a gestão do conhecimento.

Com as etapas claramente definidas e a explicação visual do que deve ser realizado em cada tarefa, colaboradores familiarizados com o processo podem suprir a ausência de quem normalmente o realiza. Ainda, fluxogramas desenhados contribuem para encurtar a curva de aprendizado de um colaborador recentemente inserido em qualquer processo da empresa.

Seja para compreender o que deve ser feito para justificar sua ausência a um dia de trabalho ou onde encontrar as informações que precisa para preencher uma planilha entregue semanalmente, a transmissão de conhecimento é mais suave com o mapeamento de processos. Mais do que isso, se evita que a qualidade de uma entrega esteja dependente da presença de quem sempre a realiza. Como levantou 
Deming (1990) é preciso "[...] estar atento ao fato de que nas organizações falta pessoal capaz de transmitir as idéias e conceitos, e por consequência, quem treine as pessoas em novas habilidades e tarefas. "(Araujo. 2007, p.231).

Segundo Tachizawa (1997) indicadores de qualidade são aqueles que buscam relacionar a percepção do cliente quanto a um produto ou serviço recebido ao grau de expectativa do mesmo em relação a este produto/serviço.

\subsection{Fluxogramas:}

Segundo Tachizawa (1997, p.236), podem ser encontrados vários tipos de gráficos que podem ser utilizados para a representação de processos tais como fluxogramas, organograma, diagrama de bloco. Para Tachizawa (1997) a adoção do fluxograma como instrumento analítico tem emprego em dois níveis de detalhamento: em nível geral, na forma de macrofluxograma, onde as tarefas são interligadas e se relacionam com o meio externo do processo; ou representando cada tarefa que compõe o processo na forma de fluxograma de colunas.

O macrofluxograma, que estabelece a visão geral do processo, pode ser elaborado a partir das tarefas identificadas na matriz de responsabilidades. A interação entre as tarefas, representada pelas linhas de interligação entre as mesmas, é identificada em função do fluxo lógico de informações e/ou documentos ao longo do processo.

De acordo com Tachizawa (1997), para efeito dos trabalhos de padronização de processos no âmbito da empresa o fluxograma é a representação gráfica da sequência de uma tarefa, sistema ou rotina de trabalho, identificando os procedimentos e correlacionando-os com as unidades organizacionais que os executam.

Tachizawa (1997) cita como principais finalidades do fluxograma: padronizar a representação dos processos, dos procedimentos e das tarefas em geral; permitir visualizar as principais áreas envolvidas, clientes internos e, principalmente, as entidades externas à empresa; facilitar a localização e a identificação dos aspectos relevantes/mais importantes do processo em foco; facilitar a leitura e o entendimento em todas as etapas do ciclo de racionalização e padronização do processo.

Já as principais características dos fluxogramas para Tachizawa (1997) vão de acordo com as fazes de sua elaboração e implantação: fase de levantamento e análise, fase de validação, fase implantação e fase de funcionamento.

Na primeira fase a principal característica é o estabelecimento de uma visão do todo, propiciando melhor compreensão do envolvimento das unidades organizacionais/setores responsáveis pela execução das operações/atividades. Além disso, continua Tachizawa (1997), há a simplificação e racionalização do trabalho por meio da localização, correção e eliminação de procedimentos desnecessários.

$\mathrm{Na}$ etapa de validação as principais características são a possibilidade do fluxograma ser usado como ilustração na exposição das atividades e a chance de facilitar a comunicação entre as pessoas envolvidas no processo desenhado. Na sua implantação os fluxogramas facilitam o treinamento dos envolvidos.

Durante o funcionamento normal do processo, determina Tachizawa (1997), os fluxogramas facilitam o treinamento dos envolvidos nos processos, servem como instrumentos de controle para os gestores do processo e nortes de atuação para os 
seus atores, assim como bases para possíveis estudos de reformulação dos processos.

Tachizawa (1997) estabelece que as informações básicas fornecidas pelos fluxogramas devem representar a natureza dos processos representados, a ordem das atividades e as áreas responsáveis por cada atividade. A atividade deve ser descrita com o verbo e objeto direto e os símbolos de início e fim devem ser usados apenas uma vez cada um por fluxograma.

As setas, por sua vez, demonstram a orientação das atividades conforme o fluxo normal de trabalho. Os símbolos colocam em evidência a origem, processamento e saída das informações. O retângulo demonstra representa alguma rotina dentro do processo, enquanto o losango indica a possibilidade de desvios para diversos outros pontos do processo. 


\section{Metodologia:}

Foram feitas entrevistas com Gerentes, Coordenadores, Especialistas e Analistas da área de Serviços do Evento do Comitê Rio 2016 para entender a avaliação deles sobre o impacto operacional do uso de processos e fluxogramas nos projetos de megaeventos.

\subsection{Tipo de Pesquisa:}

Quanto aos fins a pesquisa realizada é descritiva, já que expõe características da utilização do mapeamento de processos e desenho de fluxogramas nos projetos de grandes eventos. Além disso, busca estabelecer correlações entre a realização do mapeamento dos processos e desenho de fluxogramas e a qualidade da entrega de grandes projetos de eventos.

Quanto aos meios utilizados é possível definir a pesquisa como participante já que, de acordo com Vergara (2007), dela tomam parte pessoas implicadas no problema sob investigação. Esse é o caso já os entrevistados são colaboradores da área cujos processos e fluxogramas estão sendo estudados.

\subsection{Universo e Amostra:}

A população da pesquisa é composta por todos os profissionais de eventos que atuam com serviços e atendimento aos espectadores, enquanto a amostra foi selecionada por acessibilidade e tipicidade, sendo escolhidos elementos devido a facilidade de contato pessoal e direto com eles e pela representatividade que possuem em relação ao público-alvo da pesquisa. Trata-se, portanto, de uma amostra nãoprobabilística.

\subsection{Sujeitos:}

Para fornecerem os dados necessários foram escolhidos como sujeitos os colaboradores do Comitê Organizador Rio 2016, da área de Serviços do Evento e que atuarão nas instalações durante a entrega dos jogos, executando os serviços de atendimento aos espectadores e lidarão com os processos mapeados e fluxogramas das atividades desempenhadas pela área.

\subsection{Coleta de Dados:}

A coleta de dados foi feita através do envio de questionários por e-mail para os entrevistados. Além do questionário aberto com sete perguntas foi realizada 
observação participante, já que o entrevistador também é colaborador da área de Serviços do Evento do Comitê Rio 2016.

Foram feitas perguntas que visam avaliar a impressão dos colaboradores da área de Serviços do Evento do Comitê Rio 2016 sobre o impacto da utilização de mapeamento de processos e fluxogramas no planejamento e durante a entrega do projeto dos Jogos Olímpicos Rio 2016. As informações solicitadas nas entrevistas foram:

a) Tem experiência na realização de grandes eventos? Quais, por exemplo?

b) Os Fluxogramas atendem às necessidades de planejamento da Equipe Central de Serviços do Evento durante o planejamento da operação para os Jogos Olímpicos Rio 2016? De que maneira?

c) Utilizar os Fluxogramas auxilia no treinamento das Equipes das instalações quanto às atividades que serão realizadas? De que maneira?

d) Os Fluxogramas reduzirão o tempo necessário para a compreensão da Equipe e dos Voluntários da instalação sobre as atividades que serão realizadas? De que maneira?

e) Os Fluxogramas serão fontes de informação durante as competições esportivas dos Jogos Olímpicos para dúvidas sobre as atividades realizadas? De que maneira?

f) Os Fluxogramas utilizados para os Jogos Olímpicos poderão ser aplicados em futuros grandes eventos que oferecerão serviços aos espectadores?

\subsection{Tratamento dos Dados:}

Em seguida a obtenção das respostas foi feito tratamento qualitativo para apresentar os resultados de forma estruturada e analisa-los. Tal escolha foi feita porque a pesquisa qualitativa permite levantar as impressões e argumentações dos colaboradores do Comitê Organizador Rio 2016 que lidam e lidarão direta e diariamente com o problema de estudo.

\subsection{Tratamento dos Dados:}

As limitações do método escolhido envolvem o tamanho do grupo entrevistado, com risco de não ser o mais representativo possível do universo estudado. Além disso, se deve considerar que os entrevistados podem dar respostas que não condizem com suas opiniões reais pelo fato de terem uma relação profissional com o entrevistador.

Por se tratar de um problema de pesquisa específico ao Comitê Organizador dos Jogos Rio 2016 a amostra escolhida teve que ser reduzida aos colaboradores da área de Serviços do Evento que estavam disponíveis no período da realização da entrevista e conseguiram responde-la dentro do prazo estipulado. 


\section{0s Jogos Olímpicos Rio 2016}

Realizada com nove anos de antecedência, em setembro de 2007, a candidatura do Rio de Janeiro para receber os Jogos Olímpicos de 2016 foi o início de uma relação, muitas vezes conturbada, que prometia grandes retornos para todas as partes envolvidas. Não era a primeira tentativa brasileira de sediar uma Olímpiada e nem a primeira vez que o país receberia um megaevento.

Pan Americano 2007, as duas edições mais recentes do Rock in Rio (2011 e 2013), a Copa do Mundo 2014 e esses Jogos Olímpicos que virão em 2016 são exemplos da capacidade local de planejar e entregar grandes oportunidades de confraternização em datas específicas. Mesmo se tratando de eventos privados, eles atestaram e confirmam que o Governo brasileiro consegue atuar em conjunto com outras entidades organizadoras para obter bons resultados nas suas entregas.

As proporções desses acontecimentos comemorativos não permitem que sua realização ocorra de maneira independente, sem compartilhamento de atividades e responsabilidades por parte da Organização e do governo local. Por exemplo, a locomoção de fãs para os shows do Rock in Rio impacta o trânsito da região onde ocorre o evento de tal maneira que a prefeitura do Rio de Janeiro tem que ser consultada durante o planejamento e atuar enquanto ele estiver ocorrendo.

Entidade organizadora e governo colaboram entre si para que todos se beneficiem. O planejamento da chegada de público tem participação da C.E.T Rio porque um esquema de trânsito para o evento bem realizado contribui para a satisfação dos consumidores do evento, o que é importante para sua cidade sede. Mídia espontânea, divulgação boca a boca e fluxo maior de turistas gerados pelo evento podem se traduzir em injeção de recursos na economia.

Toda essa coordenação compartilhada de atividades obedece a uma sequência específica para que se atinja o resultado esperado. Os locais de entrada e saída de público do Rock in Rio, por exemplo, são definidos em conjunto com a C.E.T Rio para essa planejar as restrições de trânsito de maneira eficaz, leia-se com menor impacto negativo, para a cidade do Rio de Janeiro e para as pessoas que irão aos shows.

Em seguida essas informações são divulgadas para as empresas de transporte coletivo de modo que elas também possam organizar sua operação para os dias de evento. Por fim a população é comunicada, podendo aqueles que são afetados pelo esquema especial de trânsito (portadores de ingresso e moradores da região, principalmente) se prepararem adequadamente.

$\mathrm{Na}$ entrega de qualquer tipo de produto ou serviço (camisas, pratos de restaurantes, conserto de eletrodomésticos ou megaeventos) há ocorrência de processos produtivos em momentos previamente determinados. Mesmo que não estejam formalizados, dentro da fábrica, do restaurante, da loja de assistência técnica e do Comitê Organizador dos Jogos Rio 2016 há conhecimento do que deve ser feito a cada momento para que se obtenha o produto/serviço final desejado. 
Como em uma fábrica, todas as matérias-primas, insumos, etapas e atividades necessárias para a "produção" dos Jogos Olímpicos Rio 2016 tem que ser coordenadas entre todos os agentes envolvidos dentro de um determinado cronograma. Essa atuação conjunta contribui para que o produto final, o evento, tenha qualidade sob o ponto de vista de seus stakeholders.

Identificação e atribuição de responsabilidades, planejamento e ordenação da execução de atividades em determinado prazo dentro de um processo produtivo são "características" que possibilitam a utilização de ferramentas de gestão, em especial o mapeamento de processos. Mesmo em diferentes organizações e níveis hierárquicos as necessidades de planejamento de atividades dos processos produtivos não variam por tipo e sim por grau

O Ministro dos Esportes, por exemplo, dialoga e articula com inúmeras entidades, empresas e pessoas diferentes para a liberação de verbas destinadas à construção ou reforma das instalações para os Jogos Rio 2016. Enquanto o Voluntário que atuará no Maracanã durante a competição de futebol também cumpre diversas etapas para que, por exemplo, consiga orientar corretamente os espectadores aos seus assentos.

Em termos de gestão de processos, o fluxograma do processo de "Liberação de Verba" envolve grande quantidade de insumos, matérias-primas, atividades a serem realizadas e informações advindas de diferentes fontes. Diversos agentes internos (do Governo) e externos podem estar envolvidos nesse processo-chave para a realização de um evento como os Jogos Olímpicos.

Já o fluxograma de "Orientação dos Torcedores" depende da interação entre Comitê Organizador Rio 2016 e Voluntário durante os processos de contratação e entre Área Funcional do Comitê e voluntário durante período de treinamento. Em seguida, da interação entre Voluntário e portador de ingresso para o direcionamento ao assento ou local desejado. Esse processo tem menos interlocutores, informações e atividades do que o processo de "Liberação de Verba".

Porém ambos podem usufruir da utilização do mapeamento de processos, dos ganhos trazidos ao desempenho das atividades e às organizações devido às visões detalhada e geral da "fabricação do produto" que ele fornece. Mais aprofundado ao final da Segunda Guerra Mundial, no início da realização dos estudos de qualidade um dos motivos que os fluxogramas de processos agregam valor às organizações é por permitirem o registro dos dados.

Isso significa que eles desenham o caminho ideal a ser percorrido para que o produto seja entregue ao cliente. Uma vez entregue é possível observar como as etapas produtivas utilizadas pelas empresas se traduzem em vendas, aceitação, satisfação, percepção de qualidade e outros indicadores relativos aos clientes.

Assim permite também, de certa maneira, ampliar a ótica da qualidade do produto: quanto a maneira que sua fabricação ocorre e quanto à percepção do cliente sobre o que foi adquirido. Nos exemplos anteriores, a verba conseguida pelo Ministro dos Esportes para a construção ou reforma das instalações pode não ter atingido a quantia determinada pela sua construtora / montadora. Assim como a orientação passada pelo Voluntário pode ter levado o espectador a um assento na arquibancada diferente do seu.

Mapear as atividades realizadas durante o processo, e identificar os responsáveis e envolvidos nas mesmas, permite que se encontre a fonte geradora dessa dissonância de resultados. Ou seja, os motivos da quantia liberada não 
equivaler ao que será necessário e do torcedor chegar a um assento diferente do que está indicado em seu ingresso. Ambos os resultados com a qualidade abaixo da esperada.

Compreender os trâmites de cada etapa de atividades do processo através do seu mapeamento permite identificar que, por exemplo, os recursos liberados foram insuficientes porque o Assessor do Ministro não conseguiu uma determinada autorização de entidades Federais. Enquanto o direcionamento do Voluntário foi equivocado porque o mapa do Maracanã utilizado em seu treinamento continha informações erradas.

Definem-se, portanto, os fatores produtivos responsáveis pela insatisfação com o produto final. Além disso, não sendo preciso realizar o processo por completo novamente para que se obtenha o resultado esperado há economia de tempo e recursos financeiros e materiais. Todos esses três fatores são essenciais quando se trata da fabricação de bens, mais ainda quando esses bens são eventos.

O fator tempo principalmente. As competições esportivas em geral têm a pontualidade como aspecto essencial, de modo a permitir sua transmissão ao redor do mundo. Caso um torcedor perca o início do jogo porque foi orientado a um assento incorreto haverá insatisfação e prejuízo às imagens de todos os organizadores do evento: COI, Comitê Rio 2016 e Governo.

Sendo assim, a possibilidade de utilização dessa ferramenta de gestão se deve a "presença universal" dos processos. Como estabeleceu Araujo (2007), processos "Aplicam-se a qualquer coisa, desde fluxo de materiais até etapas de venda ou manutenção de produtos. "Uma fábrica, uma empresa, uma loja e uma equipe operacional do Comitê Organizador Rio 2016 tem que realizar uma sequência definida de atividades dentro de prazo específico para produzir suas entregas. Os processos e suas técnicas de utilização podem, então, também ser úteis para o planejamento e a realização de eventos.

Nessa relação entre diversas entidades para a "fabricação" dos Jogos Olímpicos Rio 2016 coube ao COI a posição de cliente do Comitê Organizador Rio 2016. Como não possui estrutura organizacional para a produção de eventos e isso também não faz parte de seu core business, o Orgão gestor do esporte olímpico mundial "contratou" um fabricante para seu produto.

Já o Governo Federal, como todos os outros governos nacionais que entram no pleito para sediar os Jogos Olímpicos, assinou compromisso de parceria com o COI e o Comitê Rio 2016. Nesse papel de contratante, é o COI que determina qual será o padrão de qualidade desejado para os aeroportos, hotéis, centros de treinamento, transportes públicos, internet e estádios no Brasil.

Dentre as inúmeras responsabilidades individuais e compartilhadas das outras duas partes, ao Governo cabe à estrutura de legado e ao Comitê Rio 2016 a operacionalização. Ou seja, se fossem de fato uma fábrica de produção de eventos, o $\mathrm{COI}$ diria as características que deseja para o produto, o Governo deveria adquirir e preparar as máquinas da linha de montagem enquanto o Comitê Rio 2016 operaria as mesmas.

Portanto não é o COI que define de que forma seus padrões seriam atingidos, quais os processos e a ordem dos mesmos para a entrega do produto. Mesmo que um fabricante de móveis permita que seu cliente "customize" seu produto, nos aspectos produtivos a autoridade é desse fabricante. Não é o consumidor que determina os 
prazos das etapas produtivas e nem mesmo a ordem de montagem que será usada para fabricar seu móvel.

O COI demanda que as regiões das instalações devem ser capazes de receber e escoar grandes multidões, que os estádios de algumas modalidades tenham capacidade para milhares de pessoas, que a cidade sede disponibilize locais para exibição gratuita das partidas, que sejam prestados serviços aos portadores de ingressos dentro dos estádios e instalações.

Para seguir essas diretrizes o governo brasileiro tem que expandir linhas de metrô e melhorar transportes públicos, reformar aeroportos, incentivar aumento da rede hoteleira, montar estruturas temporárias, construir e ampliar estádios. Tudo que envolve a realização de obras para que os locais utilizados pelas equipes e atletas nacionais e torcedores durante o evento esteja dentro do padrão estabelecido pelo COI

Com as "máquinas" dessa fábrica dos Jogos Olímpicos Rio 2016 sendo montadas, o Comitê Organizador deverá operá-las. Fazer essa linha de montagem funcionar envolve atividades como: Contratar e capacitar colaboradores e voluntários, adquirir e distribuir os materiais operacionais necessários, auxiliar na logística de entrada no país e distribuição dos materiais das seleções e atletas, atender às solicitações delas e prestar serviços aos espectadores nos locais de competição, entre outras coisas.

Todo esse turbilhão de atividades estará ocorrendo em locais novos e com padrões novos para as instalações já existentes. O COI estabeleceu um nível de serviço que nunca tinha sido visto antes para os estádios no país. Novidade mesmo para os colaboradores do Comitê Rio 2016 que tem experiência na realização de partidas de futebol do campeonato Brasileiro ou dos Estaduais, partidas da Liga Mundial de Vôlei ou do torneio Athina Onassis. As operações do Comitê Rio 2016 estão sendo planejadas, praticamente, "do zero".

A complexidade das tarefas realizadas por seus "executores" é impactada pelo tamanho atual da organização do evento, sua relevância no cenário esportivo mundial e seu apelo televisivo.

Números tão expressivos contribuem para a importância da utilização de ferramentas de gestão de processos no planejamento e execução das entregas. Atividades de atendimento ao torcedor nos estádios e instalações, por exemplo, devem ser replicadas com o mesmo padrão nas quatro macrorregiões de competição diferentes. Além disso, tudo que é documentado poderá ficar como legado para a realização de grandes eventos no país seguindo padrões de qualidade maiores do que os atuais.

Os números dos Jogos contribuem também para o Brasil ocupar as atenções da mídia global durante os meses que precedem o evento e o período da sua realização, tendo seus aspectos culturais, políticos e econômicos observados e analisados. As atenções dos outros países e da população local não estão voltadas somente para o que ocorrerá dentro dos estádios e instalações, mas para a sociedade brasileira também.

A satisfação dos que estão na ponta final do processo produtivo, os portadores de ingresso, é considerada essencial. Eles virão ao país, vivenciarão nossa cultura e compartilharão suas impressões com o resto do mundo. Para o COI e para o Brasil, é preciso deixar uma boa impressão nos consumidores, fazer com que a experiência de ir a uma competição dos Jogos Olímpicos supere as suas expectativas. 
O COI percebeu que para conseguir isso deve estender sua relação com o torcedor, um dos seus clientes finais. A forma escolhida para tanto é a prestação de serviços gratuitos para os fãs dentro dos locais de competição. Para os Jogos Olímpicos Rio 2016 eles terão à sua disposição: informações sobre a instalação, modalidade, competição e sobre a cidade-sede; guarda de itens achados e perdidos, local para armazenar carrinhos de bebê; serviços de mobilidade e assistência para portadores de necessidades especiais.

Operacionalmente, para o Comitê Organizador Rio 2016, isso se traduz na criação da área de Serviços do Evento. As entregas "produzidas" por essa área serão a linha de frente de interação e relacionamento entre o $\mathrm{COI}$ e os torcedores dentro das arenas, estádios e instalações utilizadas nos Jogos.

Todas as equipes do Comitê nos locais de competição possuirão os mesmos organograma e modo de operação: a autoridade máxima do Comitê será o Venue General Manager, ou Gerente Geral da Instalação. Durante os meses de realização do evento ele responderá à diretoria do Comitê Rio 2016, que estará reunida em um "centro de coordenação" operacional. Os Gerentes Gerais serão os responsáveis locais pela interlocução entre as áreas operacionais.

Abaixo deles se desenhará a estrutura hierárquica de funcionamento das instalações. Primeiro os Venue Managers (gerentes de instalação) de cada Área Funcional, que gerenciarão suas áreas e equipes operacionais nos locais de competição e interagirão com as outras Áreas Funcionais. Abaixo deles ficam os seus Deputies (Coordenadores).

Esses coordenadores, finalmente, tinham abaixo deles uma equipe de analistas, assistentes e, não menos importantes, voluntários. Como o cronograma de contratações prevê que as funções operacionais das instalações sejam preenchidas apenas pouco tempo antes dos Jogos, essa força de trabalho será treinada extensivamente sobre suas funções pela equipe do Escritório Central do Comitê Rio 2016 durante o período pré-evento. À medida que a data de realização dos Jogos se aproxima, as equipes das instalações crescerão em tamanho, e o desafio de capacitálas também.

Os coordenadores e gerentes deverão então replicar localmente o treinamento recebido para capacitar suas próprias equipes e voluntários locais. Os processos serão utilizados para auxiliar nessa troca de informações entre tantas "mãos" diferentes de diversas maneiras: seu desenho e mapeamento auxiliarão na transmissão do conhecimento e reduzirão perdas de conteúdo, facilitando o treinamento, definindo um padrão único de atuação e que servirá como norte no caso de dúvidas.

Nos meses de maio, junho, julho e agosto de 2016, ápice da realização do evento, somente o Estádio Olímpico (Engenhão) contará com mais de 50 colaboradores e 500 voluntários exclusivos. Será preciso que todas essas pessoas exerçam suas tarefas da maneira correta e em coordenação com as atividades alheias para que operação das competições ocorra dentro do nível de serviço definido pelo COI em conjunto com o Comitê Rio 2016.

As equipes da área de Serviços do Evento que atuarão nos estádios possuirão Manuais Operacionais desenvolvidos pela Equipe Central e os desenhos dos fluxogramas de processos serão parte integrante desses Manuais. O desafio do Comitê Rio 2016 e dos seus colaboradores será, portanto, seguir uma mesma linha de 
coordenação e execução de todos os seus processos operacionais para atingir o nível de qualidade exigido pelo $\mathrm{COI}$ em todas as instalações das 43 diferentes modalidades.

Meios e instrumentos para, remotamente, controlar e avaliar o treinamento e a atuação das equipes locais serão essenciais para a área de Serviços do Evento. Pois será a única área do Comitê Rio 2016 cujos clientes externos são os, aproximadamente, 8 milhões de espectadores que irão às instalações durante os Jogos.

Para a Equipe Central de Serviços do Evento, armazenar itens perdidos dentro dos estádios ou prestar os outros serviços da maneira correta significará que as atividades mapeadas nos Manuais Operacionais estarão sendo seguidas. Ainda, se as etapas desenhadas nos fluxogramas não forem cumpridas é porque o resultado do treinamento foi abaixo do esperado. Será uma forma de mensurar a qualidade do serviço prestado e de sua "produção" local.

Tal iniciativa de busca pela excelência através do desenho e uso de fluxogramas está de acordo com o que afirmou Araujo (2007), portanto, sobre mapeamento de processos e a qualidade caminharem juntos. Segundo ele, "[...] é a partir dos estudos dirigidos à gestão da qualidade total que profissionais e estudiosos deram ênfase à análise de processos e daí até a gestão global, estratégica, dos processos. "

Pela natureza do produto entregue pela área de Serviços do Evento, a aplicação do mapeamento de processos e desenho de fluxogramas foca na logística de recursos humanos. Será necessário que os Gerentes de Instalação da área, aqueles que atuarão somente nas instalações, saibam como prestar os serviços e consigam ensinar seus analistas, assistentes e voluntários a também fazer isso. Sendo que, na maioria dos casos, nenhum desses envolvidos tem qualquer experiência prévia no assunto.

Será responsabilidade desses Gerentes de Instalação fazer com que os voluntários de Serviços do Evento em cada instalação atendam o portador de ingresso da mesma maneira. Isso quer dizer sempre oferecer: locomoção em cadeiras de rodas, achados e Perdidos para objetos e pessoas; colocar pulseiras de identificação em menores de idade; guarda de carrinhos de bebê e orientação em geral sobre a instalação, a modalidade esportiva e a cidade-sede.

Cabe, portanto, à equipe do Escritório Central entender as necessidades dos clientes, levantar e documentar dados, analisá-los e desenvolver soluções para a prestação de serviços ao espectador nos estádios. A primeira etapa do planejamento foi identificar as atividades e nomeá-las, dar motivos à sua existência, definir quem seria responsável por elas e qual seria o produto resultante delas.

Em seguida definiram-se como as atividades poderão ser realizadas operacionalmente. Serão formalizados os procedimentos de atendimento ao cliente em instalações esportivas durante os Jogos Olímpicos através do desenho dos fluxogramas desses processos. Serão estabelecidas metas de como atender a todas as solicitações de locomoção em cadeiras de rodas, distribuir pulseiras para todas as crianças menores de idade no estádio, devolver todos os objetos perdidos encontrados e comunicar corretamente informações a todos os clientes da área, os torcedores.

Antes da Copa do Mundo e dos Jogos Olímpicos a expectativa dos espectadores ao adquirirem ingressos para competições esportivas no Brasil era, em geral: deslocar-se a região da instalação de competição; ingressar na mesma; possivelmente consumir algum alimento ou bebida nos bares da instalação; assistir à competição e, 
então, sair da instalação e do seu entorno para seu próximo destino. Partindo dessas etapas básicas desse comportamento do consumidor é que se pensou em formas de agregar valor a essa experiência.

Em todas as instalações em que Serviços do Evento estará presente a atenção dos Gerentes de Instalação se voltará aos detalhes da execução das atividades e no desenvolvimento da empatia da equipe. Ter a capacidade de se colocar no lugar do outro será primordial para o atendimento aos portadores de ingresso e os fluxogramas auxiliam na visualização, por parte dos que serão treinados pelos Gerentes de Instalação, de como será a situação real de prestação dos serviços.

Focando em aspectos visuais e orais para orientação e divulgação de suas atividades, Serviços do Evento utiliza diversas ferramentas para cumprir a proposta de relacionamento com os torcedores que o COI idealizou para os Jogos. Objetos como placas de mão, cadeirões, megafones, coletes e lanternas farão parte dos mais de quarenta mil itens usados, direta e indiretamente, na prestação dos serviços disponíveis.

Nas entradas das instalações, a operação de Serviços do Evento começa com a divisão e organização de filas e direcionamento dos espectadores para os detectores de metais e aparelhos de Raio-X. Em seguida os espectadores serão guiados às tendas de leitura de ingresso para enfim adentrarem as instalações. Nos espaços de circulação de público a divulgação da informação visará garantir que o espectador encontre seu assento e saiba sobre serviços que estarão disponíveis a ele, assim como sobre a estrutura da instalação (lojas oficiais do evento, bares, banheiros, posto médico).

As instalações escolhidas e montadas / construídas para sediar as competições dos Jogos Olímpicos Rio 2016 são, muitas vezes, estruturas prediais complexas com diversos níveis, salas, escadas comuns e de emergência, banheiros, cozinhas e bares, camarotes e setores de arquibancadas. Atender os espectadores nos locais onde o público tem acesso nessas instalações será responsabilidade de Serviços de Evento.

Ainda, por se tratar de um evento internacional a presença de espectadores estrangeiros será intensa. Dessa maneira a equipe orientará em mais de uma língua e todos que tenham domínio de língua estrangeira estarão identificados. A sinalização será preparada se buscando reduzir as barreiras linguísticas através da comunicação visual e utilização de pictogramas.

Tanto para a orientação quanto para a prestação de seus serviços todo o planejamento da área de Serviços do Evento girará em torno de um elemento primordial: consistência da informação. A escolha por esse foco não foi à toa já que instalações esportivas novas ou reformadas funcionarão de maneira nunca antes vista em qualquer competição já disputada no país.

Além disso um evento do gabarito dos Jogos Olímpicos será "consumido" por estrangeiros e habitantes que não estão acostumados a frequentarem estádios. Mais do que consumir esporte, os portadores de ingresso compraram entretenimento e Serviços do Evento auxiliará na diversão dos fãs ao oferecer produtos que tornarão essa experiência de consumo mais agradável.

Essa democratização de acesso ao produto acarreta em um perfil de cliente com necessidades dentro de uma instalação esportiva que poucas existentes no Brasil estão aptas a atender. Estrangeiros, cadeirantes, obesos, gestantes e muitas famílias estão entre os compradores de ingressos. Isso permite que se pense em disponibilizar 
serviços que continuarão a ser prestados durante os campeonatos locais seguintes aos Jogos.

Os fluxogramas de processos dos serviços prestados serão utilizados durante todos os 6 meses de treinamento das equipes das instalações para os Jogos Olímpicos e também "in loco", impressos e expostos, por exemplo, nas paredes das Salas Operacionais e Balcões de Informações para que a equipe de Serviços do Evento possa se orientar quando necessário for.

Toda a informação e conteúdo gerados, portanto, "trocarão de mão" 4 vezes: da Equipe Central para os Gerentes de Instalação; desses para seus Coordenadores, Supervisores, Analistas e, em seguida, para os Voluntários. E então para os espectadores. Será necessário, portanto, a padronização das informações para que sua transmissão seja feita da melhor forma possível.

A opção pelos serviços disponíveis aos portadores de ingressos para as instalações está relacionada às questões de segurança do evento, seu porte e imagem. Com concentração de milhares de pessoas em espaços reduzidos onde serão realizadas competições esportivas que animam e envolvem os que estão assistindo, o atendimento e orientação aos torcedores é importante por motivos de segurança e pela grande chance de ocorrências como perda de itens e crianças separadas dos pais.

Caberá à área de Serviços do Evento a tarefa de armazenar esses itens sem dono aparente encontrados nos estádios, identificar os menores de idade para facilitar o encontro com seus responsáveis caso se percam e, entre outras coisas, auxiliar na locomoção de pessoas com mobilidade reduzida.

Com esses serviços será possível, por exemplo, que os espectadores que perderam itens se dirijam a um local específico dentro da instalação para verificar se o seu objeto foi encontrado. Em caso positivo, irão então recuperá-lo após confirmar que são os donos de fato.

Guardar e devolver objetos encontrados perdidos dentro da arena era um serviço que implicava responsabilidades para a organização do evento. Era preciso que as atividades detalhadas do processo fossem cumpridas para garantir que os itens armazenados até retornar ao seu dono não fossem danificados. Além disso, era crucial garantir que o item correto era devolvido ao seu verdadeiro dono.

Também devido a grande quantidade de pessoas em um mesmo local durante curto período de tempo, muitas das quais não familiarizadas com os estádios, é que foram baseados os serviços de Pessoas Achadas e Perdidas e identificação infantil. No caso de idosos, menores de idade ou qualquer outro tipo de pessoa se perdesse de seu acompanhante a equipe e os voluntários de Serviços ao Espectador atuavam no reencontro das partes.

O primeiro passo era comunicar a situação no rádio e aguardar por 5 minutos no mesmo local, dando chance da parte que não estava presente aparecer. Em seguida se encaminhava o perdido ou quem o procurava a um local pré-definido dentro do estádio. Locais com a função de ponto de encontro e referência da equipe de STS para os espectadores foram distribuídos ao longo dos estádios.

Visualizando todas as etapas e atividades do processo que cuidava desse reencontro através do mapeamento de processos, a Equipe Central desenvolveu uma maneira de reduzir sua ocorrência. Colocar pulseiras em menores de idade com as informações e o contato de seu responsável. Assim, o serviço de identificação infantil era importante na prevenção de problemas relacionados a pessoas perdidas. 
Já a guarda de carrinhos de bebê era relativa à segurança do estádio, tanto no caso de confusões dentro dele quanto na necessidade de evacuá-lo caso alguma emergência ocorresse. Também estava relacionado a atender torcedores que queriam, ou tinham que, levar crianças de colo aos jogos da Copa.

A partir de um agendamento realizado em local específico do estádio, fornecendo informações pessoais e contato, um serviço de locomoção em cadeiras de rodas estava disponível. Todos os espectadores com condições reduzidas de mobilidade poderiam utilizá-lo. Esse serviço também contava com agendamento de local e horário de busca para locomoção a algum local do estádio após o final da partida.

Para organizar a realização de todas as atividades que faziam parte dos serviços prestados pela área de Serviços ao Espectador a presença de formulários foi indispensável. Reunir as informações de todos que solicitavam atendimento na forma de serviços através dessa ferramenta de gestão serviu para organizar e controlar as atividades, pontos importantes para sua qualidade. 


\section{Análise dos Resultados}

Todos os entrevistados na pesquisa participaram de projetos de grandes eventos esportivos, tais como: Jogos Pan Americanos do Rio de Janeiro 2007, Copa do Mundo da FIFA do Brasil 2014, Jogos Mundiais Militares do Rio de Janeiro 2011. Além disso, todos também têm vivências na realização de grandes eventos esportivos já realizados no Brasil, por exemplo: Etapas da Liga Mundial de Vôlei e do Grand Prix de Judô; Provas do Campeonato Mundial de Motovelocidade e da Fórmula Indy.

As principais menções a respeito do uso dos fluxogramas para atender às necessidades do planejamento operacional durante a etapa de projeto dos Jogos Olímpicos do Rio 2016 foram: unificar as informações e nortear o conteúdo a ser desenvolvido. Cem por cento dos colaboradores entrevistados, que estão inseridos no planejamento da entrega dos Jogos, considera que os fluxogramas feitos a partir do mapeamento de processos atingem suas expectativas.

Durante a entrega do projeto as atividades operacionais, que foram mapeadas e desenhadas, serão aplicadas em diversas instalações ao longo do Rio de Janeiro e do Brasil. Assim os entrevistados foram perguntados sobre a utilidade dos fluxogramas na transmissão de conhecimento para os colaboradores que atuarão somente nessa etapa e não estiverem envolvidos no projeto do evento.

Quanto a isso, a totalidade dos respondentes afirmou que os fluxogramas auxiliam no treinamento dessas equipes locais. Tal fato é relevante já que esses colaboradores específicos das instalações também deverão instruir e auxiliar os voluntários no desempenho das atividades deles, junto dos que fizeram parte do projeto.

Além disso foram levantadas características positivas dos fluxogramas e da sua utilização para a troca de conteúdo: simplificar e sintetizar a informação a ser transmitida, facilitando sua compreensão por parte das equipes locais; padronizar a forma como as atividades serão executadas e permitir que esse mesmo conteúdo seja transmitido em todas as diferentes instalações que terão atuação da área de Serviços do Evento; aplicabilidade dos fluxogramas não somente para processos, mas também para hierarquias e cadeias de comunicação (reports).

Mesmo convergindo na opinião de que a forma dos fluxogramas para demonstrar informações permite que a curva de aprendizado seja reduzida, cinquenta por cento dos pesquisados ressaltam que não basta ter as atividades mapeadas e desenhadas. Como tanto colaboradores pagos, quanto voluntários podem ter vivências em eventos distintas é preciso simplicidade e objetividade nos fluxogramas desenvolvidos sem espaço para mais de uma interpretação.

Noventa por cento dos envolvidos na pesquisa considera que no momento da entrega do projeto, onde a execução das atividades da área de Serviços de Evento estará ocorrendo continuamente, os fluxogramas servirão como referência e fonte de consulta. Ou seja, no dia a dia de uma instalação durante os Jogos, com competições 
seguidas, o desenho do mapeamento de processos será utilizado para retirar dúvidas sobre como e o que fazer para executar os serviços entregues pela área.

Quarenta por cento dos entrevistados ressaltou outra característica positiva dos fluxogramas ao afirmar que eles são o primeiro passo para a contabilização de dados das atividades mapeadas que poderão ser usados para a atuação da área de Serviços de Evento em edições dos Jogos Olímpicos que estão por vir.

Finalmente, todos os entrevistados concordam que os desenhos em fluxogramas das atividades operacionais desempenhadas a partir do mapeamento de seus processos poderão ser utilizados em futuros projetos e entregas de grandes eventos nos quais nos quais serão prestados serviços aos espectadores.

Abaixo encontram-se os desenhos dos fluxogramas dos serviços prestados pela área de Serviços do Evento para os espectadores durante as competições esportivas: 


\section{FLUXOGRAMA DE ARMAZENAMENTO DE CARRINHOS DE BEBE - EVS}

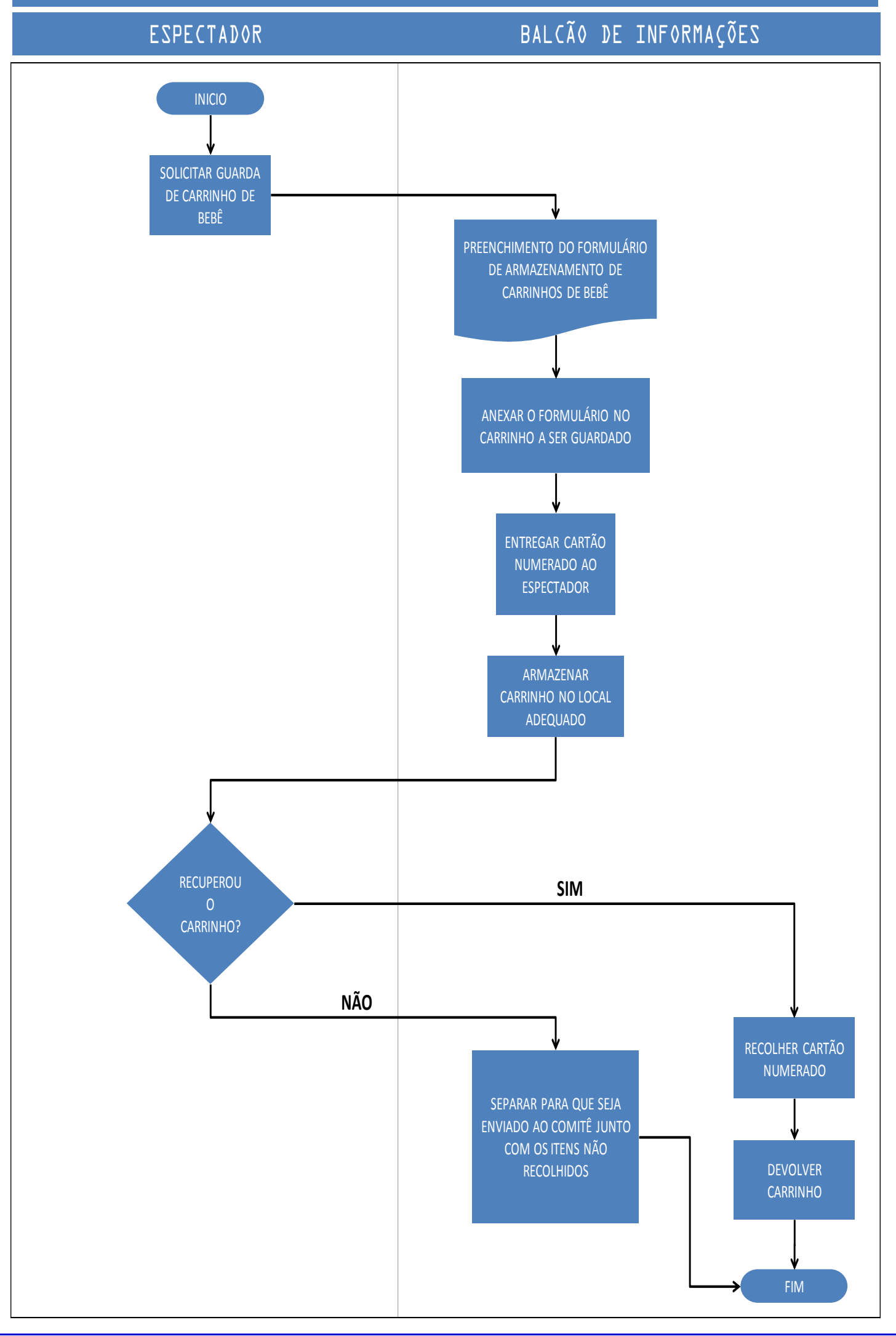




\section{FLUXOGRAMA DE ITENS PERDIDOS - EVS}

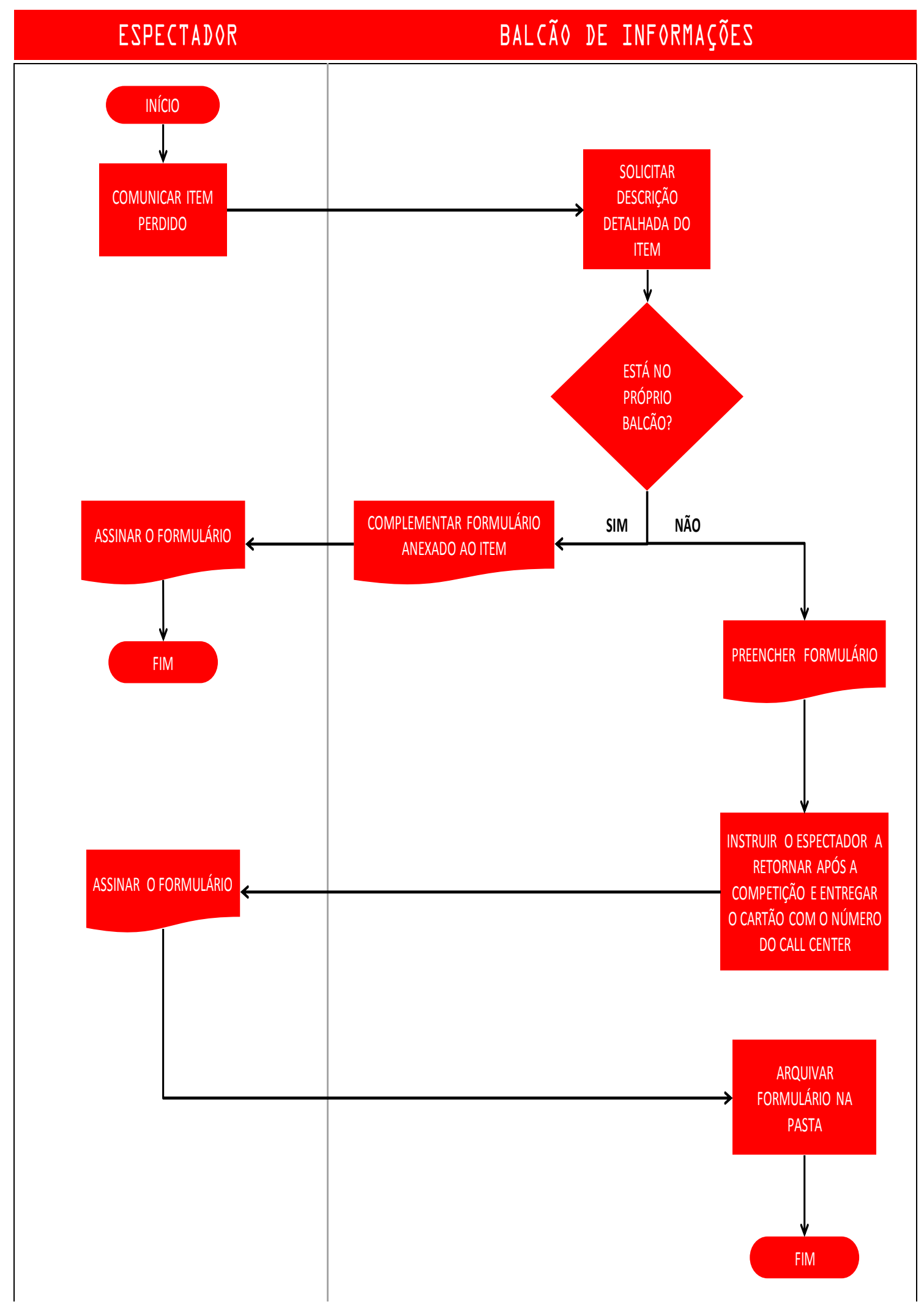




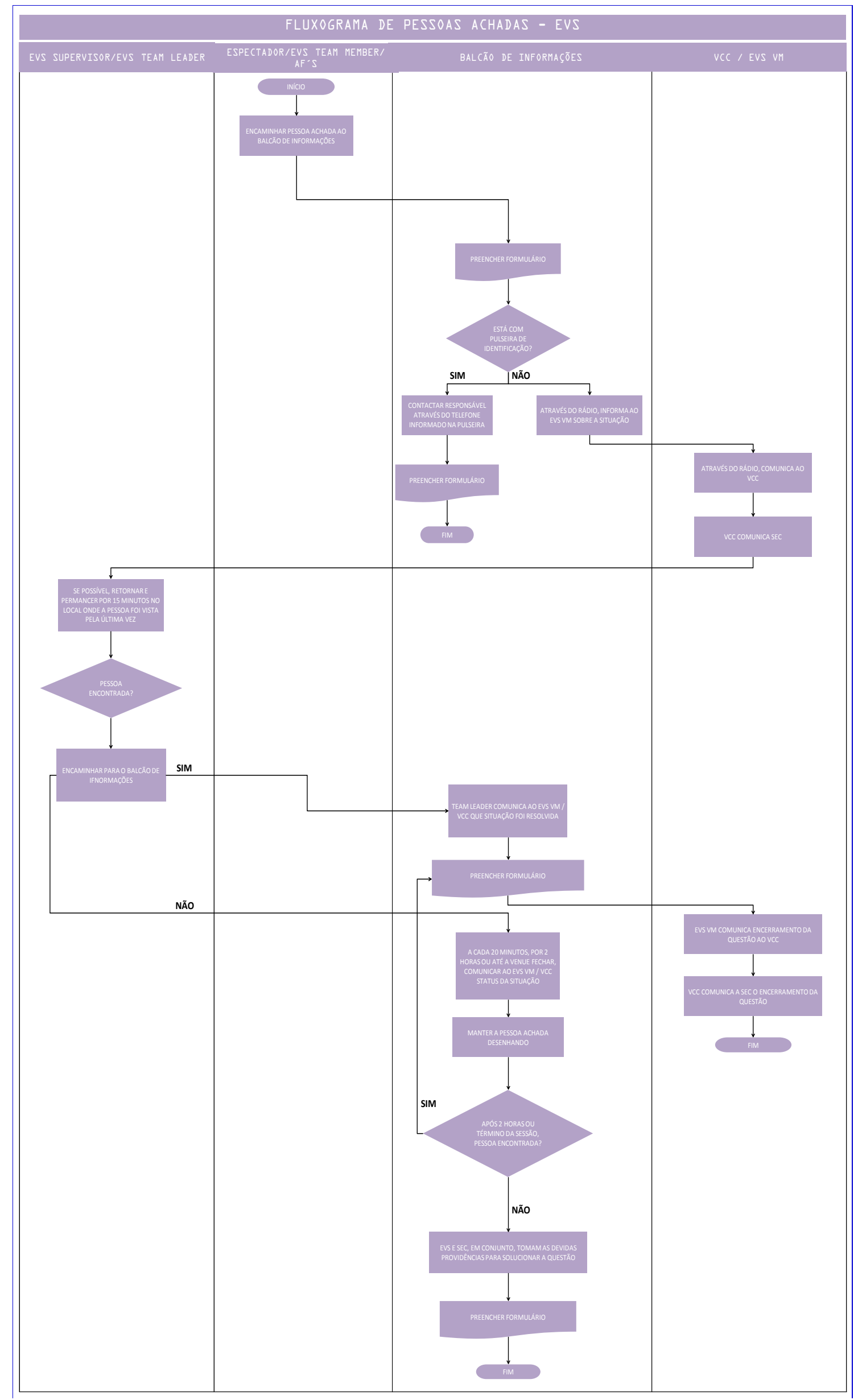




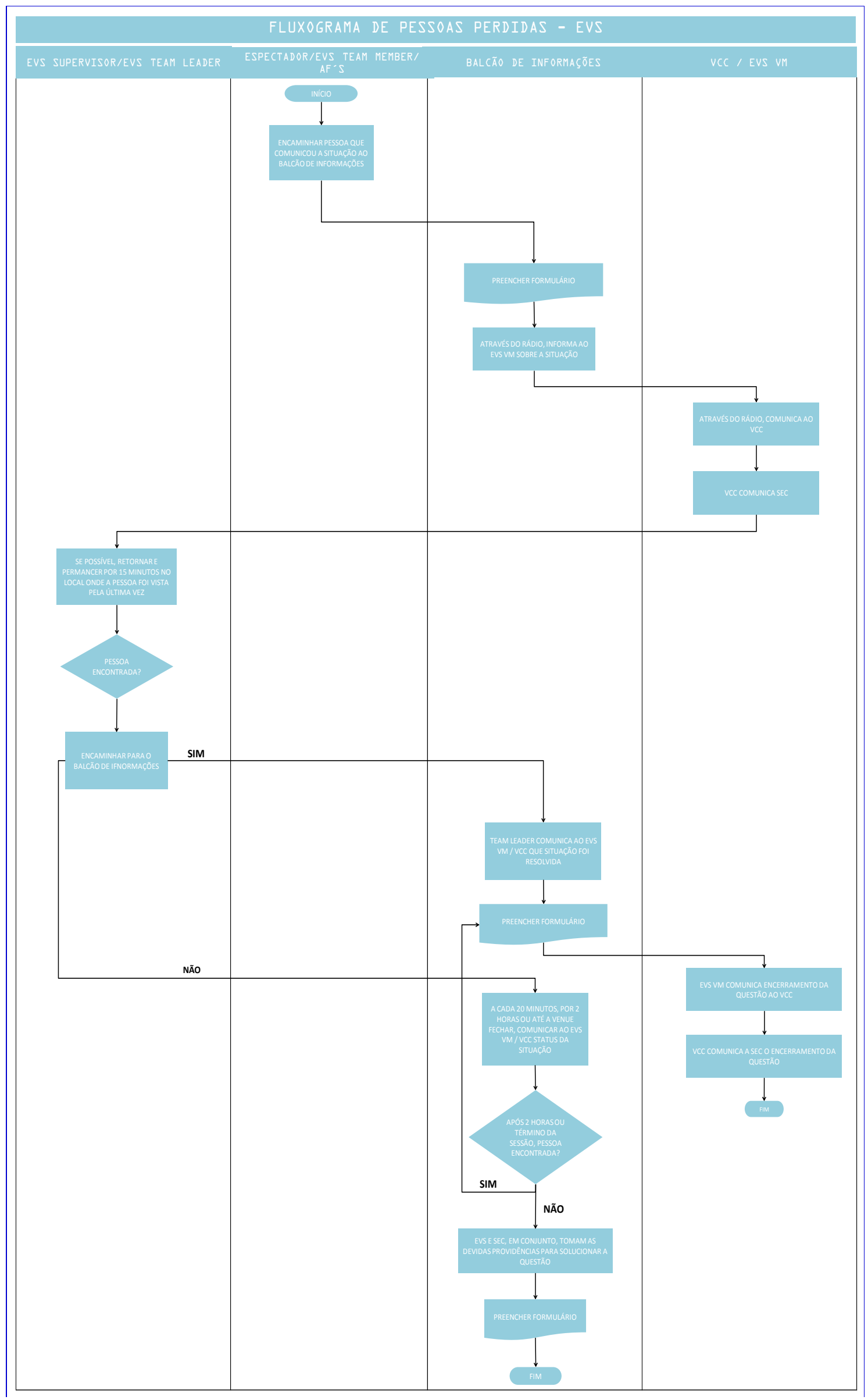




\section{FLUXOGRAMA DE SERVIÇO DE CADEIRA DE RODAS - EVS}

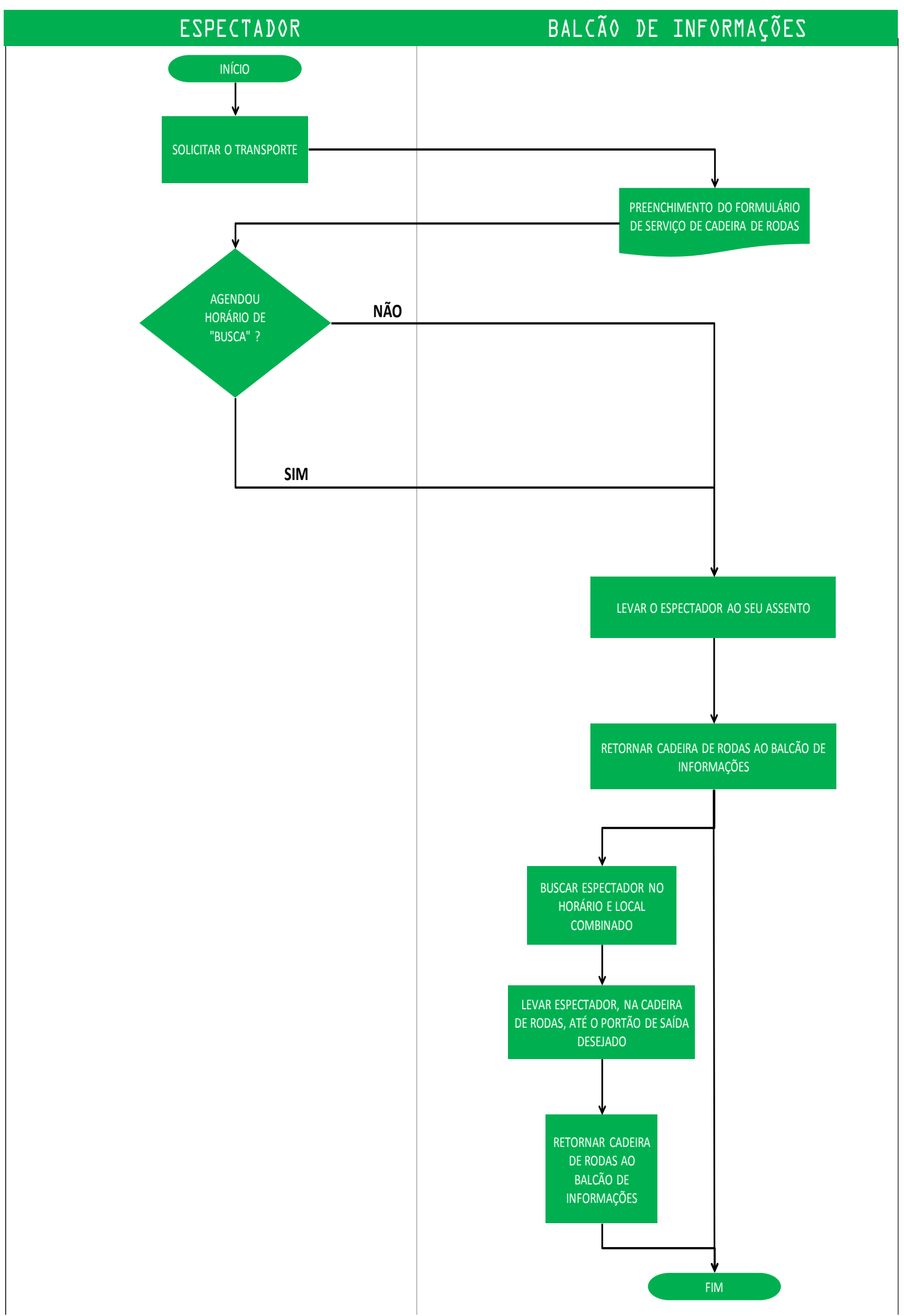




\section{FLUXOGRAMA DE ITENS ACHADOS - EVS}

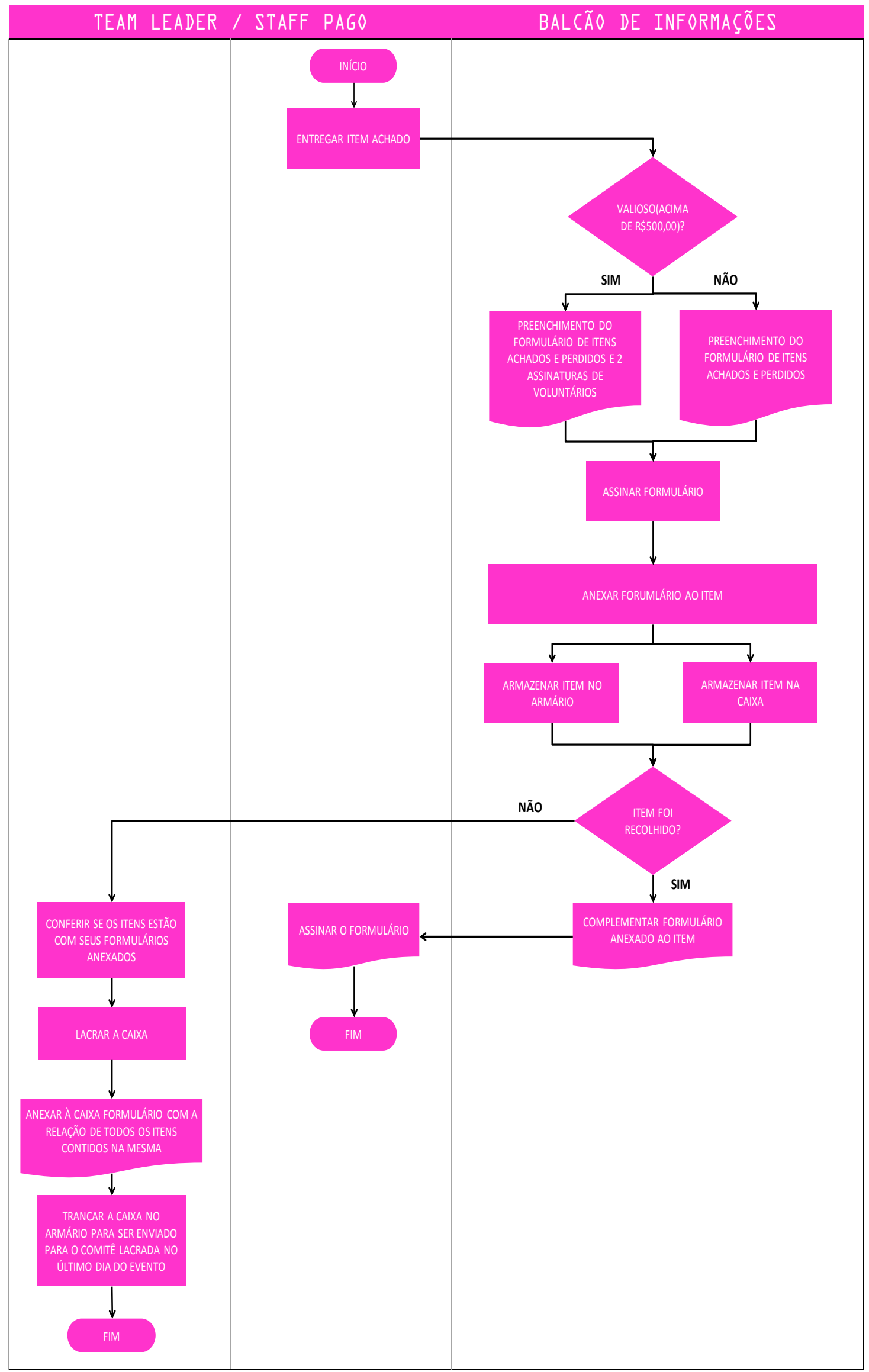




\section{Considerações Finais:}

Dentro do projeto dos Jogos Olímpicos Rio de Janeiro 2016 a área de Serviços do Evento é responsável pelas atividades que atendem às necessidades dos espectadores dentro das instalações esportivas. Dentro desse atendimento está a prestação de alguns serviços como: achados e perdidos de objetos, ponto de encontro de pessoas perdidas, identificação infantil, locomoção de espectadores em cadeiras de rodas.

Rapidamente atender às solicitações dos espectadores, entregar os serviços no prazo e sem retrabalho envolvem a qualidade de acordo com o ponto de vista do realizador da tarefa e de acordo com quem ela é destinada, conforme estabeleceu Araujo (2007).

Durante o projeto dos Jogos Olímpicos Rio 2016, o mapeamento dos processos das atividades operacionais que serão desempenhadas pela área de Serviços do Evento na fase da entrega condiz com a "fórmula de sucesso" para a qualidade segundo Juran (1992): estabelecer metas que devem ser atingidas, traçar planos indicando como fazer isso e definir responsabilidades para obtenção dos resultados.

Essa fórmula da qualidade condiz com a definição de fluxograma dada por Tachizawa (1997) de que ele é a representação gráfica da sequência de uma tarefa e identifica os procedimentos realizados, correlacionando-os com os responsáveis por sua execução.

Quando questionados sobre a utilização dos fluxogramas dos processos mapeados para atender às necessidades de planejamento da área de Serviços de Evento dos Jogos Rio 2016, seus colaboradores afirmam que as finalidades da utilização dessa ferramenta, segundo Tachizawa (1997), foram atingidas. Ou seja, para eles os fluxogramas que estão sendo utilizados padronizam a representação das tarefas e facilitam a leitura e o entendimento das atividades em todas as etapas do processo.

Obedecendo aos conceitos de processos segundo Cruz (2007) e Araujo (2007), os colaboradores envolvidos no projeto dos Jogos Olímpicos Rio 2016 mapearam todos os elementos que compõe os processos operacionais executados: insumos, recursos, atividades, informações, procedimentos, ordem cronológica das etapas e sua duração e, finalmente, suas metas e clientes.

O mapeamento dos processos e seu desenho em fluxogramas, de acordo com os colaboradores envolvidos no projeto entrevistados, permite também que seja feita uma reflexão sobre aspectos tangíveis das atividades que envolvem questões financeiras. Por exemplo: mapeando o processo de achados e perdidos para espectadores dentro das instalações é possível observar a quantidade de pessoas envolvidas em sua realização, assim como materiais e equipamentos utilizados. Sendo 
assim, se fazem estimativas de custos necessários para equipamentos e voluntários de modo a realizar as atividades mapeadas e desenhadas.

Mais ainda, esse trabalho de compreensão e mapeamento das atividades atende o conceito definido por Zanela (2012) para a operacionalização de eventos, promovendo a integração das diversas atividades técnicas nas respectivas especializações através de uma unidade responsável. Se observa que a impressão dos colaboradores da área de Serviços do Evento envolvidos no projeto é de que os fluxogramas nortearão os serviços aos espectadores nas diversas instalações onde a área atuará.

Essa grande quantidade de instalações esportivas condiz com os fatores levantados por Flyvbjerg (2014) para caracterizar os Jogos Olímpicos Rio 2016 como um megaprojeto: empreitadas complexas e em grande escala, com anos de desenvolvimento, atores públicos e privados e com a ambição de alterar, mesmo que temporariamente, a estrutura da sociedade na qual estão sendo realizados.

A utilização do mapeamento de processos e desenho dos fluxogramas por parte dos colaboradores do Comitê Organizador Rio 2016 condiz com a ideia de Flyvbjerg (2014) de que tantos recursos em tantos megaprojetos fazem com que, atualmente, seu gerenciamento esteja em seu momento de maior importância.

Além disso, segundo Flyvbjerg (2014), dados estatísticos mostram que durante as etapas de planejamento a complexidade das atividades de entrega do projeto tendem a ser ignoradas. Isso pode acarretar na inadequação das contingências de tempo e orçamento. Com a utilização do mapeamento de processos e desenho de fluxogramas é possível detalhar as atividades de modo a melhor compreender suas particularidades.

A partir das impressões dos colaboradores dos Jogos Olímpicos Rio 2016, que possuem experiência prévia em projetos de megaeventos esportivos, é possível concluir que o mapeamento de processos e o desenho de seus fluxogramas contribui para tentar equilibrar o "paradoxo dos megaprojetos", identificado por Flyvbjerg et al. (2003). Ele estabelece que, apesar da realização de megaprojetos estar cada vez mais em voga, o desempenho da gerência dos mesmos não apresentou melhoras em termos de prazo, custo e benefícios nos últimos 70 anos dos quais se dispõem dados comparativos.

Isso porque a padronização das atividades, o norteamento das equipes e a redução da curva de aprendizado quanto aos serviços que serão prestados aos espectadores são resultados da utilização de fluxogramas por parte da equipe de Serviços do Evento dos Jogos Olímpicos Rio 2016, de acordo com as pesquisas realizadas para esse trabalho. $E$ esses aspectos permitem um planejamento centralizado dessas atividades, assim como dos seus prazos, recursos e condições.

Maior conhecimento sobre esses aspectos, em um momento no qual o gerenciamento de projetos está em destaque, permite melhor adequação das contingências de tempo e orçamento do projeto com a realidade da entrega. $O$ mapeamento de processos e a utilização de fluxogramas são, portanto, ferramentas úteis na realização de projetos de eventos com grande escala e grande duração e que envolvem bilhões de dólares. Ou seja, megaprojetos para megaeventos. 


\section{Referências Bibliográficas}

AALTONEN, K., et al. A project lifecycle perspective on stakeholder influence strategies in global projects. Scandinavian Journal of Management, 26. 2010.

ALVES. J. F. Legado da Copa Para a Segurança Pública é Discutível. ConsultorJurídico. Belo Horizonte. 24 jun 2014. Disponível em: < http://www.conjur.com.br/2014-jun-24/josias-alves-legado-copa-seguranca-publicadiscutivel >. Acesso em: 24 de Outubro de 2014.

DE ARAUJO, L. C. G. Organização, Sistemas e Métodos e As Técnologias de Gestão Organizacional. Volume 1. $3^{\circ}$ Edição. São Paulo. Atlas. 2007.

BLOG SPUTNIK. Audiência dos Jogos do Rio 2016 Poderá Alcançar 5 Bilhões de Pessoas no Mundo Todo. Brasil, 2014. Disponível em: < http://br.sputniknews.com/brasil/20150410/724542.html > Acesso em: 30 de outubro de 2014.

CAMPOS, E. Copa 2014 Trará R\$142 Bi ao Brasil. Época Negócios. São Paulo. 29 jun 2014. Disponível em: < http://epocanegocios.globo.com/Revista/Common/0,ERT149593-16357,00.html >. Acesso em: 27 de Outubro, 2014.

CANTARELLI, C. C, et al. Lock-in and its influence on the project performance of large-scale transportation infrastructure projects: Investigating the way in which lock-in can emerge and affect cost overruns. Environment and Planning B: Planning and Design, 37. 2010.

CARVALHO, F. Datafolha Mostra que Brasileiros tem Aprovado a Copa do Mundo de 2014. 180 Graus. São Paulo, 3 jul 2014. Disponível em: < http://180graus.com/copa/datafolha-mostra-que-brasileiro-tem-aprovado-a-copa-domundo-2014 > . Acesso em: 22 de Outubro, 2014.

COMITÊ ORGANIZADOR. Transparência / Orçamento. Brasil, 2015. Disponível em: < http://www.rio2016.com/jogo-aberto/orcamento > Acesso em: 24 de abril de 2015.

CRUZ, T. Sistemas, Organização \& Métodos, 3 Edição, São Paulo, Atlas, 2007.

DRUMMOND, H. Is escalation always irrational? Organisation Studies. 1998. 
FIFA. Transmissões por TV Atingem Número Recorde. Rio de Janeiro. 2014. Disponível em: < http://pt.fifa.com/worldcup/news/y=2014/m=6/news=transmissoespor-tv-atingem-numeros-recordistas-2388437.html >. Acesso em: 17 de Outubro de 2014.

FLYYBJERG, B. Megaproject planning and management: Essential readings. Cheltenham, UK. Edward Elgar. 2014.

FLYYBJERG, B. From Nobel Prize to project management: Getting risks right. Project Management Journal, 37(3). 2006.

FLYYBJERG, B. et al. Megaprojects and risk: An anatomy of ambition. Cambridge, England: Cambridge University Press. 2003.

GIOVANNI, B. Comitê Organizador da Copa Estoura Orçamento e Gastará R\$1 bi. Blog do BG. São Paulo. 22 mar 2014. Disponível em: < http://blogdobg.com.br/comiteorganizador-da-copa-estoura-orcamento-e-gastara-r-1-bi/ $>$. Acesso em: 25 de Outubro de 2014.

GLOBO ESPORTE. Final da Copa do Mundo Bate Recorde de Audiência nos Estados Unidos. Washington, EUA. 14 jul 2014. Disponível em: < http://globoesporte.globo.com/futebol/copa-do-mundo/noticia/2014/07/final-da-copa-domundo-bate-recorde-de-audiencia-nos-estados-unidos.html $>$. Acesso em 20 de Outubro de 2014.

KANTOR, D. Brasil 2014: Copa com Recorde de Público e de Publicidade. Clarin. Buenos Aires, Argentina. 3 jul 2014. Disponível em: < http://www.clarin.com/br/BrasilCopa-recorde-publico-publicidade 0 1141686208.html >. Acesso em: 22 de Outubro de 2014.

KOTTLER, P. Administração de Marketing. $10^{\circ}$ Edição. São Paulo. Prentice Hall. 2000.

MAgAlhaES, V. “Copa Muda Percepção das Pessoas Sobre o Brasil”, diz Torcedor Alemão. UOL. Salvador. 16 jun 2014. Disponível em: < http://copadomundo.uol.com.br/noticias/redacao/2014/06/16/copa-muda-a-percepcaodas-pessoas-sobre-o-brasil-diz-torcedor-alemao.htm >. Acesso em: 20 de Outubro de 2014.

PATU, G. Custo da Copa Equivale a Um Mês de Gastos com Educação. Folha de São Paulo. Brasilia. 23 mai 2014. Disponível em: < http://www1.folha.uol.com.br/poder/2014/05/1458720-custo-da-copa-equivale-a-ummes-de-gastos-com-educacao.shtml >. Acesso em: 24 de Outubro de 2014.

PORTAL TERRA. Embratur Detalha Campanha Para Ter 400 Mil Turistas em 2016. Brasil, 2015. Disponível em: < http://esportes.terra.com.br/jogosolimpicos/2016/embratur-detalha-campanha-para-ter-400-mil-turistas-em- 
2016,3eaa0a9d3c84c410VgnVCM4000009bcceb0aRCRD.html > Acesso em: 14 de fevereiro de 2015.

PORTAL R7. Brasil Recebeu 1 Milhão de Turistas Estrangeiros Durante a Copa.São Paulo. 2014. Disponível em: < http://esportes.r7.com/futebol/copa-domundo-2014/brasil-recebeu-1-milhao-de-turistas-estrangeiros-durante-a-copa14072014> Acesso em: 22 de Outubro, 2014.

REBELLO, K. Olimpíada de 2016 Já Custa $\mathbf{R} \$ 36,7$ bi e Supera Copa em $43 \%$. Brasília e Rio de Janeiro, 2014. Disponível em: < http://esporte.uol.com.br/rio2016/ultimas-noticias/2014/04/16/orcamento-olimpiada-de-2016.htm > Acesso em: 30 de outubro de 2014.

ROSS, J. STAW, B. M. Organizational escalation and exit: Lessons from the Shoreham Nuclear Power Plant. The Academy of Management Journal, 36(4). 1993.

TACHIZAWA, T. et al. Organização Flexível, São Paulo, Atlas, 1997.

TALEB, N. N. The black swan: The impact of the highly improbable. Second edition. New York, NY: Penguin. 2010.

VERGARA, S. Projetos e Relatórios de Pesquisa em Administração. $9^{\circ}$ edição, São Paulo, Atlas, 2007.

ZANELLA, L. C. Manual de Organização de Eventos - Planejamento e Operacionalização. $5^{\circ}$ Edição. São Paulo. Atlas. 2012. 